\title{
Glutaminases as a Novel Target for SDHB-Associated Pheochromocytomas/Paragangliomas
}

\author{
Balazs Sarkadi 1,2, Katalin Meszaros ${ }^{2,3,4}$, Ildiko Krencz ${ }^{5}$, Letizia Canu ${ }^{6}$ (1) Lilla Krokker 2,4, \\ Sara Zakarias ${ }^{1}$, Gabor Barna ${ }^{5}$, Anna Sebestyen ${ }^{4,5}$, Judit Papay ${ }^{5}$, Zoltan Hujber ${ }^{5}$, \\ Henriett Butz ${ }^{2,3,4,7}$, Otto Darvasi ${ }^{2,4}$, Peter Igaz ${ }^{1,8}{ }^{\circ}$, Judit Doczi ${ }^{9}$, Michaela Luconi ${ }^{6}$, \\ Christos Chinopoulos 9 (D) and Attila Patocs $2,3,4,7, *$ \\ 1 2nd Department of Internal Medicine, Semmelweis University, 1088 Budapest, Hungary; \\ sarkadi.balazs2@med.semmelweis-univ.hu (B.S.); sarazakarias@gmail.com (S.Z.); \\ igaz.peter@med.semmelweis-univ.hu (P.I.) \\ 2 Hereditary Tumours Research Group, Hungarian Academy of Sciences and Semmelweis University, \\ 1085 Budapest, Hungary; kati.balla@gmail.com (K.M.); krokker.lilla@gmail.com (L.K.); \\ butz.henriett@med.semmelweis-univ.hu (H.B.); otto.darvasi@gmail.com (O.D.) \\ 3 Department of Laboratory Medicine, Semmelweis University, 1089 Budapest, Hungary \\ 4 Bionics Innovation Center, 1088 Budapest, Hungary; sebestyen.anna@med.semmelweis-univ.hu \\ 5 1st Department of Pathology and Experimental Cancer, Semmelweis University, 1085 Budapest, Hungary; \\ krencz.ildiko@med.semmelweis-univ.hu (I.K.); barna.gabor@med.semmelweis-univ.hu (G.B.); \\ papay.judit@med.semmelweis-univ.hu (J.P.); zoltan.hujber56@gmail.com (Z.H.) \\ 6 Department of Experimental and Clinical Biomedical Sciences "Mario Serio", University of Florence, \\ 50139 Florence, Italy; letizia.canu@unifi.it (L.C.); Luconi.michaela.luconi@unifi.it (M.L.) \\ 7 Department of Molecular Genetics, National Institute of Oncology, 1122 Budapest, Hungary \\ 8 Molecular Medicine Research Group, Hungarian Academy of Sciences and Semmelweis University, \\ 1085 Budapest, Hungary \\ 9 Department of Medical Biochemistry, Semmelweis University, 1094 Budapest, Hungary; \\ doczi.judit@med.semmelweis-univ.hu (J.D.); chinopoulos.christos@med.semmelweis-univ.hu (C.C.) \\ * Correspondence: patocs.attila@med.semmelweis-univ.hu; Tel.: +36-1-266-0926; Fax: +36-1-266-0816
}

Received: 5 February 2020; Accepted: 1 March 2020; Published: 5 March 2020

Abstract: Pheochromocytoma/paragangliomas (Pheo/PGL) are rare endocrine cancers with strong genetic background. Mutations in the $S D H B$ subunit of succinate dehydrogenase (SDH) predispose patients to malignant disease with limited therapeutic options and poor prognosis. Using a host of cellular and molecular biology techniques in 2D and 3D cell culture formats we show that SDH inhibition had cell line specific biological and biochemical consequences. Based on our studies performed on PC12 (rat chromaffin cell line), Hela (human cervix epithelial cell line), and H295R (human adrenocortical cell line) cells, we demonstrated that chromaffin cells were not affected negatively by the inhibition of SDH either by siRNA directed against SDHB or treatment with SDH inhibitors (itaconate and atpenin A5). Cell viability and intracellular metabolite measurements pointed to the cell line specific consequences of SDH impairment and to the importance of glutamate metabolism in chromaffin cells. A significant increase in glutaminase-1 (GLS-1) expression after SDH impairment was observed in PC12 cells. GLS-1 inhibitor BPTES was capable of significantly decreasing proliferation of SDH impaired PC12 cells. Glutaminase- 1 and SDHB expressions were tested in 35 Pheo/PGL tumor tissues. Expression of GLS1 was higher in the SDHB low expressed group compared to SDHB high expressed tumors. Our data suggest that the SDH-associated malignant potential of Pheo/PGL is strongly dependent on GLS-1 expression and glutaminases may be novel targets for therapy.

Keywords: succinate; SDH; SDHB; pheochromocytoma; paraganglioma; GLS-1 


\section{Introduction}

The unique metabolic environment of cancers is long known [1]. Pheochromocytomas/paragangliomas (Pheo/PGL) are rare (incidence: 0.8 per 100,000 person-years [2]) chromaffin cell derived neoplasms. In the past decade, enzymes of the tricarboxylic acid (TCA) cycle became the center of attention, because variants of genes encoding the subunits of succinate dehydrogenase enzyme [3-6], fumarate hydratase [7], malate dehydrogenase type 2 [8], and aspartate aminotransferase [9] enzymes have been associated with development of Pheo/PGL. The most widely accepted assumption is that defects of tricarboxylic acid (TCA) cycle may result in accumulation of certain, so called oncometabolites (such as succinate, fumarate, D-2-hydroxyglutarate [10]) which contribute to cancer development. Succinate competitively inhibits the 2-oxoglutarate (2-OG)-dependent HIF prolyl-hydroxylases in the cytosol [11,12], which results in stabilization and activation of HIF- $1 \alpha$ therefore a shift to a pseudo-hypoxic environment occurs. This phenomenon is further demonstrated by the highly vascular phenotype of these tumors. In addition, chronic hypoxia (i.e., high altitudes) increases the incidence of sporadic PGLs and it has been demonstrated that it has a phenotype modifier effect on germline SDHB and SDHD mutant PGLs [13-16].

Even though germline mutations of genes encoding for $S D H$ subunits have been shown to predispose susceptibility for the development of familial Pheo/PGL, only mutations of the SDHB gene have been often associated with high rate of malignancy. Metastatic disease can be observed in more than $17-40 \%$ of patients with SDHB mutations [17-19], but the mechanisms leading to the malignant phenotype are still unclear. The lack of a useful in vivo animal model for the development of Pheo/PGLs highly determines the experimental opportunities. [20]. Due to the lack of response to the currently available therapy for malignant Pheo/PGL, novel and easily accessible in vitro models for this tumor are required in order to evaluate the candidate therapies and to uncover new prognostic and therapeutic targets.

Glutamine is a major source of carbon for nucleotide and non-essential amino acid biosynthesis [21], and its metabolism supports cell proliferation [22]. Glutamine also serves as an energy source through glutamine-driven oxidative phosphorylation [23], as it replenishes TCA intermediates. SDHB-deficient cells show increased glutamine incorporation, which might be used as a shuttle for aspartate from the mitochondria to the cytosol to support cellular anabolism [24]. Glutamine metabolism also yields precursors for glutathione production, thus plays an important role in maintaining the redox homeostasis of cancer cells [25-27]. Furthermore, glutaminolysis supports substrate-level phosphorylation during hypoxia in tumors [28].

Located in the mitochondria, glutaminase-1 (GLS-1) generates glutamate from glutamine. Glutamate can be further metabolized to $\alpha$-ketoglutarate, by glutamate dehydrogenase (GDH), which can directly fuel the TCA cycle. GLS-1 has been found to be upregulated in some cancers, and in some cases deregulated glutamine metabolism is essential for cancer growth [29-32]. SDHx mutant tumors were shown to accumulate lower levels of glutamate [33], and SDHB knockout cells were shown to be more sensitive to GLS-1 inhibitors [34]. Targeting glutamine metabolism in SDH deficient cancer is emerging as an ongoing trial (NCT02071862) including, inter alia, SDH associated gastrointestinal stromal tumors and non-gastrointestinal stromal tumors. However, to date, there are only very limited published data available about the efficacy of GLS-1 inhibitors in SDHB related malignancies [35].

Itaconate is a natural metabolite, in vivo it is synthesized in macrophages from cis-aconitate by cis-aconitase, coded by Irg1 (immunoresponsive gene 1) in order to dysregulate bacterial metabolism [36]. Itaconate contributes to macrophages' antimicrobial activity by inhibiting isocitrate lyase of bacteria [37,38] and to limit neuronal Zika virus infection by inducing an antiviral intracellular metabolic state [39]. Itaconate can reduce the activity of SDH in vitro [40] in a dose dependent manner, but has no effect on other mitochondrial pathways [41].

In addition, it was shown that itaconate can facilitate tumor progression through a ROS-driven pathway [42]. It was demonstrated that peritoneal tissue-resident macrophages promote tumor 
progression in certain tumors, including melanoma and ovarian carcinoma by tumor induced Irg1 expression resulting in high itaconic acid levels. This pro-tumor effect was associated with the reactive oxygen species mediated MAPK activation in tumor cells [43], to the best of our knowledge, there are no data examining the effects of itaconate on cell survival.

Atpenin A5 (atpenin) is an SDH inhibitor that binds in the ubiquinone binding pocket comprised of residues from $\mathrm{SDH}$ subunits $\mathrm{B}, \mathrm{C}$, and $\mathrm{D}$, blocking the electron transfer between the enzyme and ubiquinone [44,45]. It is important to note that the inhibition of SDH with atpenin could not induce hypoxia mediated gene expression in monocytes [46] and a dose dependent reduction of cell survival after treatment with atpenin analogues has been shown [47].

In this current work we aimed to study the biological and metabolic consequences of accumulation of succinate obtained through pharmacological and translational inhibition of the SDH enzyme in various cancer cell lines and using siRNA knockdown of $S d h b$ in rat pheochromocytoma cell line, PC12. Our complex in vitro study revealed that SDH inhibition facilitated the viability of chromaffin cells but not the non-chromaffin cells. Selective inhibition of GLS-1 enzyme decreased the proliferation of SDH impaired PC12 cells in monolayer and in 3D tissue culturing. Based on our in vitro findings, we detected an upregulation of GLS-1 in SDHB-low expressed Pheo/PGL tumors compared to SDHB highly expressed Pheo/PGLs. Our data pointed to the importance of the choice of cell line for studying SDH impairment and indicated the potential prognostic role and therapeutic target of GLS- 1 enzyme in $S D H$-associated malignant Pheo/PGL.

\section{Results}

\subsection{Sdhb Targeting siRNA Effectively Decreased SDH Activity}

PC1 2 cells were transfected with two different $S d h b$ targeting siRNAs. After $48 \mathrm{~h}$ incubation, SDH activity SDHB protein levels and succinate/fumarate ratios were assessed. SDH activity was effectively reduced after siSdhb transfection compared to mock transfected and untreated cells (Figure 1A-D). siSdhb transfection showed similar potential in inhibiting SDH activity to atpenin, a potent and known SDH inhibitor (Figure 1D). Combination of two SDHB targeting siRNAs effectively reduced SDHB protein levels (Figure 1E,F and Figure S1). Succinate/fumarate ratio increased significantly in cells transfected with siRNA against $S d h b$ compared to cells transfected with mock siRNA $(p<0.0001)$ (Figure 1G). 
$\mathbf{A}$

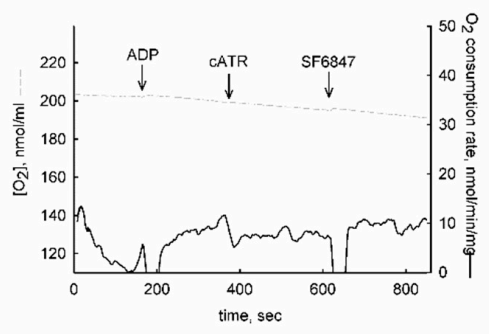

B

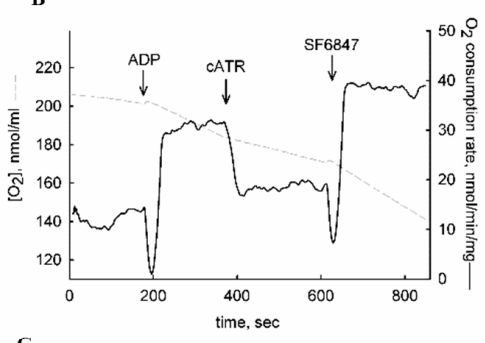

C

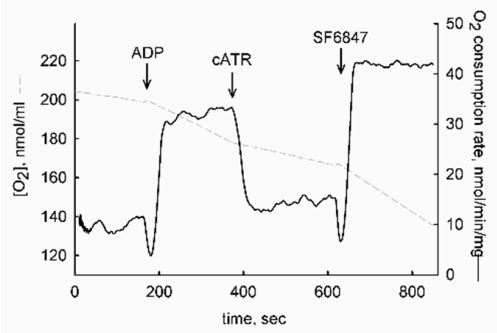

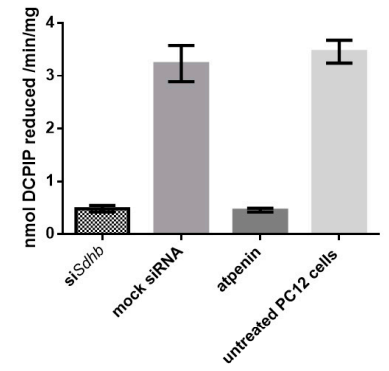
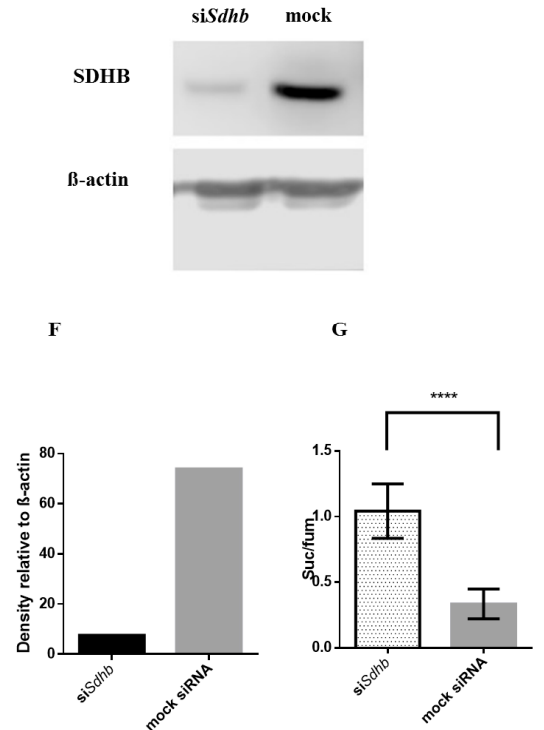

Figure 1. Effects of $S d h b$ knockdown in PC12 cells. (A-C) Oxygen consumption PC12 cells. Grey trace represents the negative time derivative of oxygen concentration, divided by mitochondrial mass per volume. Additions of substances are indicated by arrows. ADP: $0.2 \mathrm{mM}$. cATR: $2 \mu \mathrm{M}$. SF 6847: $1 \mu \mathrm{M}$. (A) Respiration of siSdhb transfected PC12 cells. (B) Respiration of mock transfected PC12 cells. (C) Respiration of untreated PC12 cells. (D) Succinate dehydrogenase (SDH) activity after siSdhb transfection, mock siRNA transfection, atpenin treatment and in untreated PC12 cells. The effectiveness of siSdhb transfection was compared to atpenin, which is a well-known potent SDH inhibitor. (E) SDHB protein level after siRNA transfection using Western blot analysis. (F) Densitometry quantification of the SDHB protein in siRNA against $S d h b$ treated and mock siRNA transfected PC12 cells. (G) Succinate to fumarate ratio in PC12 cells transfected with SDHB targeting siRNA (siSdhb) compared to mock transfected cells. suc/fum: succinate to fumarate ratio. ${ }^{* * * *}: p<0.0001$.

\subsection{Itaconic Acid Treatment Successfully Inhibited SDH Activity in All Cell Lines Studied}

Succinate/fumarate ratio significantly increased in PC12 cells after $24 \mathrm{~h}(p<0.0001)$ and $48 \mathrm{~h}$ $(p<0.0001)$ itaconate treatment. (Figure S2A)

Similar to PC12 cells, significant increase in succinate/fumarate ratio was observed in HeLa cells after $24 \mathrm{~h}(p<0.0001)$ and $48 \mathrm{~h}(p<0.0001)$ itaconate treatment, as well as in H295R cells after $24 \mathrm{~h}$ $(p<0.0001)$ and $48 \mathrm{~h}(p<0.0001)$ itaconate treatment. (Figure S2B,C)

\subsection{Atpenin Treatment Successfully Inhibited SDH Activity in All Cell Lines Studied}

Succinate/fumarate ratios due to the immeasurable concentrations of fumarate in case of atpenin treatment could not be calculated. However, SDH activity was also successfully inhibited by atpenin treatment based on the significant $(p<0.0001)$ increase in succinate concentrations and the significant $(p<0.0001)$ fold increase in succinate levels in all cell lines, compared to control (Figure S3). 


\subsection{Cell Viability and Proliferation}

2.4.1. SDH Impairment Had an Overall Positive Effect on Cell Viability Without Significant Changes in the Proliferation in PC12 Cells

Sdhb knockdown significantly increased PC12 cells' viability after $72 \mathrm{~h}(p=0.04)$ compared to mock transfected cells whereas significant differences were not observed at 24 and $48 \mathrm{~h}$. (Figure 2A). A significant difference was observed in itaconic acid treated PC12 cells compared to vehicle treated cells after $24 \mathrm{~h}(p=0.026)$ but not at 48 and $72 \mathrm{~h}$ (Figure 2B). Atpenin treatment yielded an increase in cell viability, but not at a significant level in the PC12 cell line (Figure 2C).
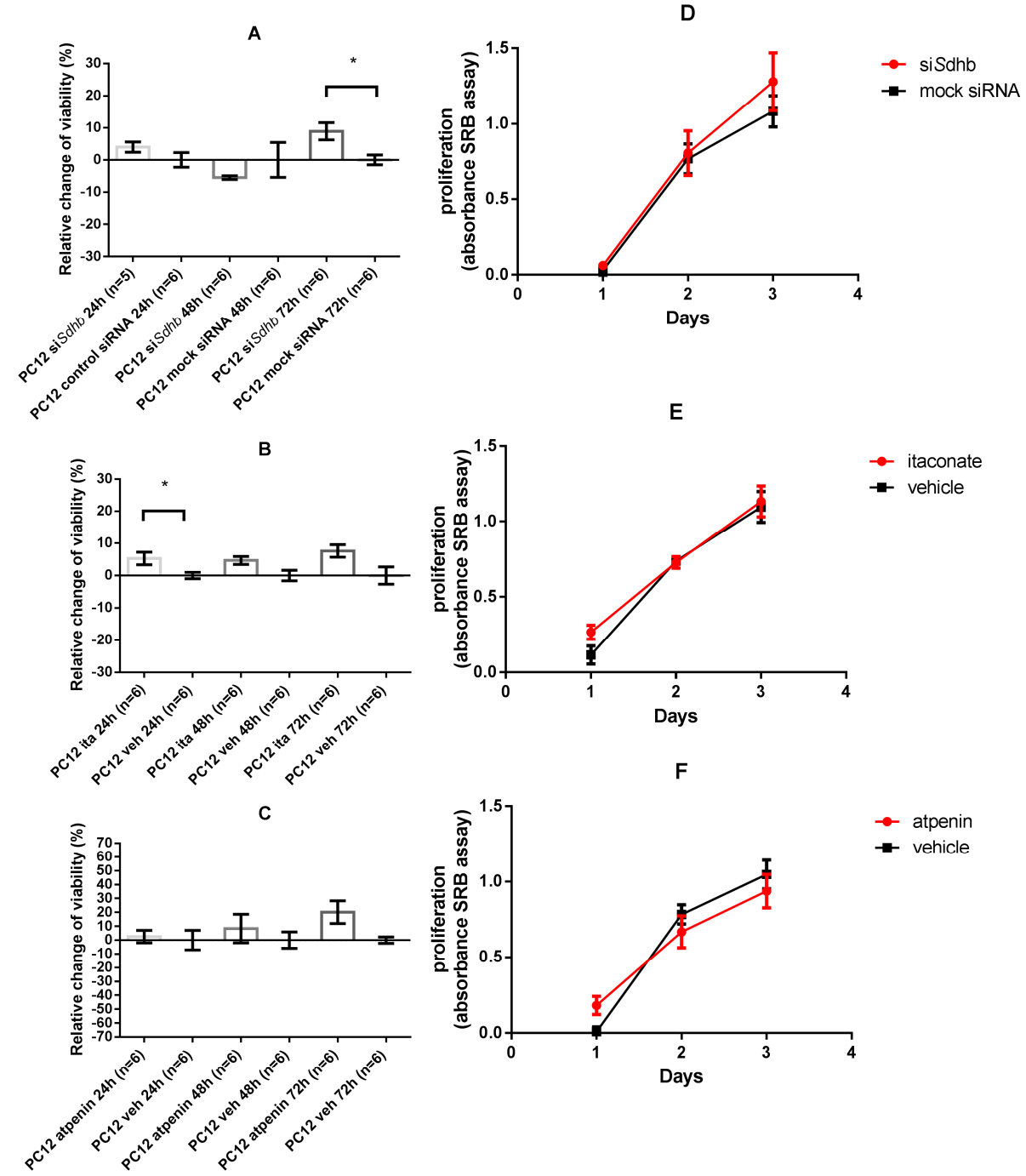

Figure 2. Cell viability and proliferation of PC12 cell lines. Data is presented in mean \pm SEM. Cell viability measurement values are normalized to the control values. A total of $100 \%$ was subtracted from the values, therefore, changes in \% compared to control are presented. (A-C) Relative change of cell viability of $S d h b$ targeting siRNA transfected, itaconate, or atpenin treated PC12 cells after 24, 48, and $72 \mathrm{~h}$ incubation, compared to control. (D-F) Proliferation of PC12 cells after Sdhb targeting siRNA transfection, itaconate, or atpenin treatment measured by SRB assay. Ita: Itaconate; veh: vehicle. SRB: Sulforhodamine $\mathrm{B} ;{ }^{*}: p<0.05$.

Cell proliferation of PC12 cells measured with SRB assay was not affected by SDH impairment either with $S d h b$ knockdown or itaconate/atpenin treatment (Figure 2D-F). 
2.4.2. Itaconate Decreased Cell Viability of HeLa and H295R Cells Whereas Atpenin Only Decreased Cell Viability in the H295R Cell Line

HeLa cells showed significant decrease in cell viability upon $48 \mathrm{~h}(p=0.002)$ and $72 \mathrm{~h}(p=0.002)$ treatment with itaconate. The opposite effect was observed after atpenin treatment of HeLa cells with significant increase in cell viability at $48 \mathrm{~h}(p=0.015)$ compared to vehicle treatment (Figure 3A,B).

A
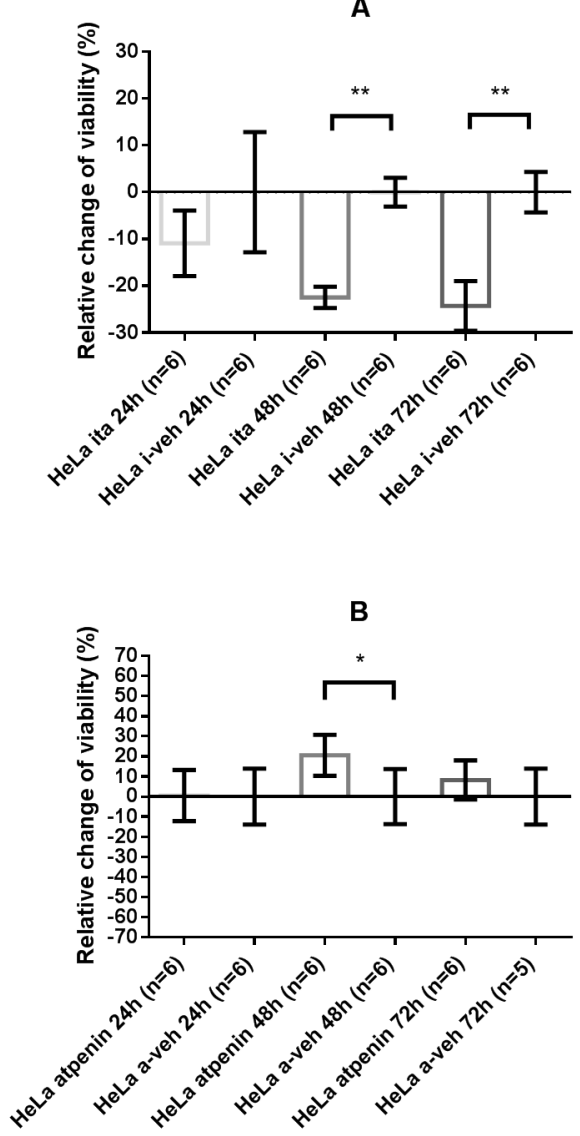

C

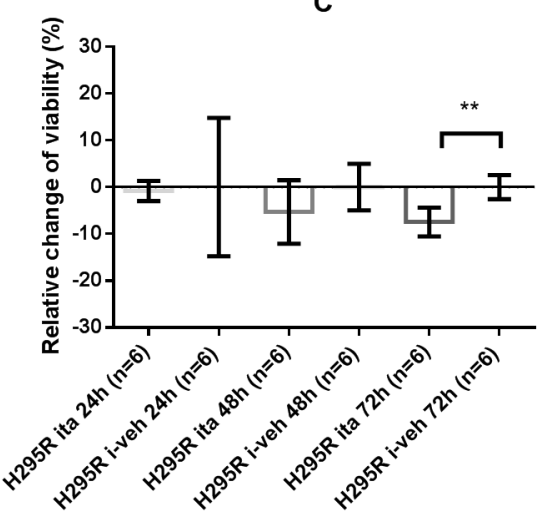

D

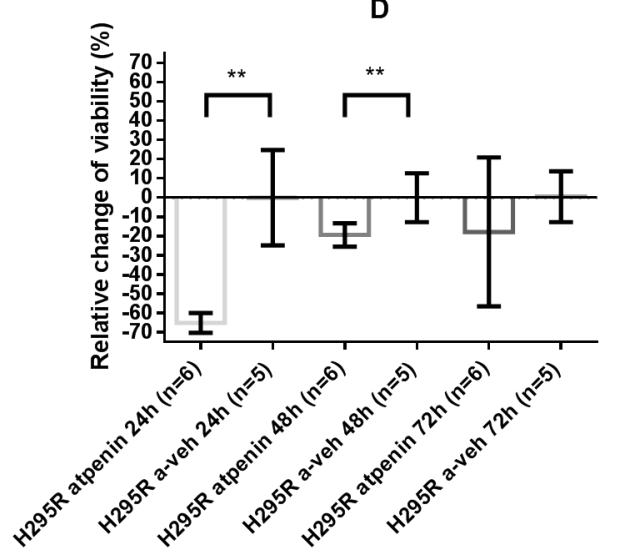

Figure 3. Cell viability measurements of HeLa and H295R cell lines. Values are normalized to the control values. A total of $100 \%$ was subtracted from the values, therefore, changes in $\%$ are presented compared to control. (A) Relative change of cell viability of HeLa cells after 24, 48, and $72 \mathrm{~h}$ itaconate treatment, compared to control. (B) Relative change of cell viability of HeLa cells after 24, 48, and $72 \mathrm{~h}$ atpenin treatment, compared to control. (C) Relative change of cell viability of H295R cells after 24, 48, and $72 \mathrm{~h}$ itaconate treatment, compared to control. (D) Relative change of cell viability of H295R cells after 24,48 , and $72 \mathrm{~h}$ atpenin treatment, compared to control. Veh: vehicle. *: $p<0.05 ;{ }^{* *}: p<0.01$.

The H295R cell line showed an overall negative response to SDH impairment: significant decrease in cell viability was observed upon itaconate treatment after $72 \mathrm{~h}(p=0.0043)$ and upon atpenin treatment after $24 \mathrm{~h}(p=0.004)$ and $48 \mathrm{~h}(p=0.017)$ (Figure 3C,D).

\subsubsection{Changes in Glutamate and Lactate Concentrations were SDH Inhibition Method and Cell} Line Specific

The metabolite concentrations for each cell line and each SDH inhibitory method are presented in Figure 4 and Figure S4, and Tables S1 and S2.

In PC12 cells metabolite concentrations measured after $S d h b$ knockdown clustered together to those measured after itaconate treatment (Figure 4B). Succinate accumulation was detected in all cell lines after inhibition of SDH activity. Sdhb knockdown significantly decreased glutamate concentrations $(p<0.0001)$ (Figure 4C), while lactate did not show accumulation (Figure 4D and Table S1). 
Glutamate levels also decreased in PC12 cells after itaconic acid treatment compared to vehicle treatment after $24 \mathrm{~h}(p=0.008)$ and $48 \mathrm{~h}(p=0.53)$ without lactate accumulation (Figure 4C,D and Table S1). Atpenin induced a significant decrease of glutamate concentrations in PC12 cells after $24 \mathrm{~h}$ $(p<0.0001)$ and $48 \mathrm{~h}(p<0.0001)$, accompanied with significant increases in lactate concentrations after $24 \mathrm{~h}(p=0.004)$ and $48 \mathrm{~h}(p<0.0001)$ (Figure 4C,D and Table S2).

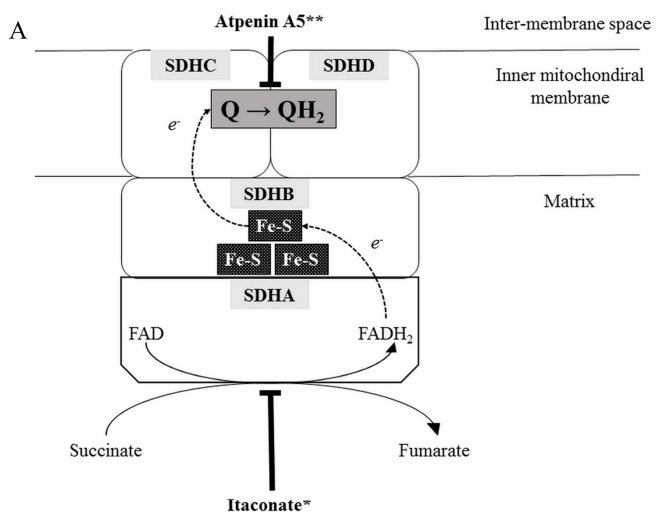

$\mathrm{C}$

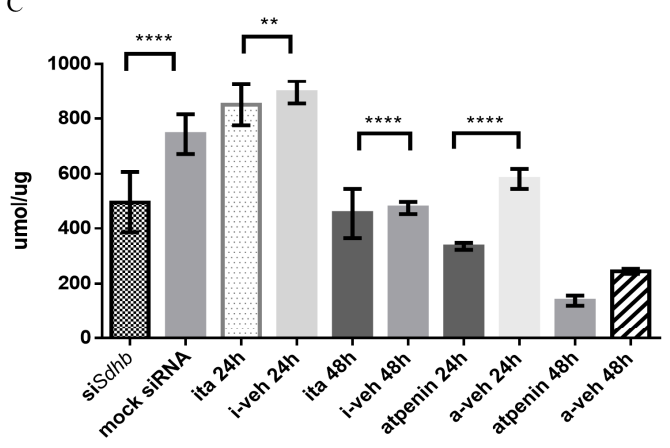

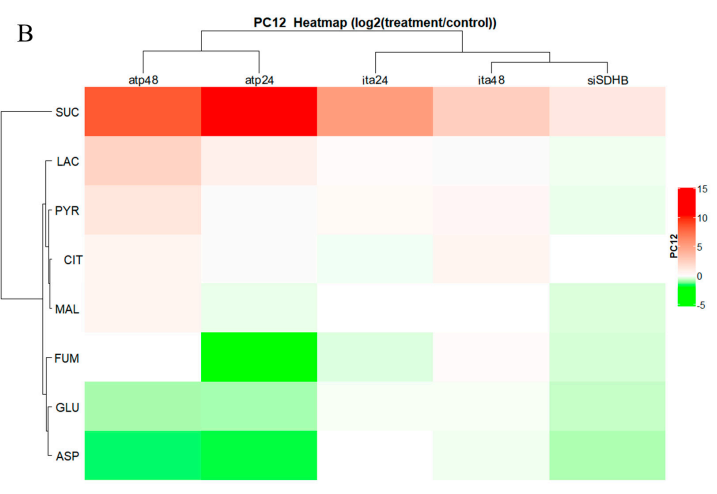

$\mathrm{D}$

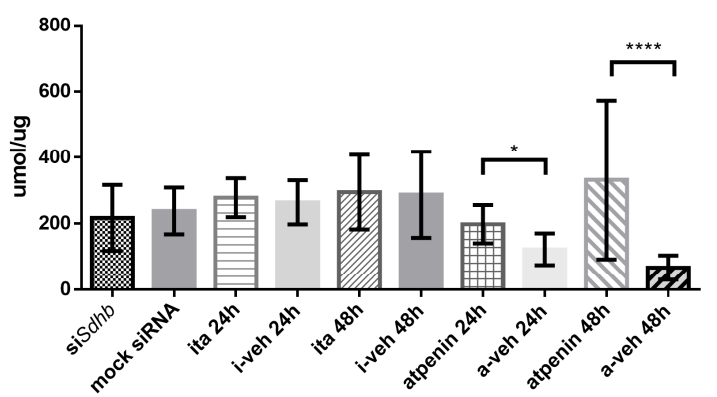

Figure 4. Inhibitory method specific changes in cellular metabolomics of PC12 cells after SDH inhibition. (A) Schematic illustration of Complex II. FAD: flavin-adenin-dinucleotide; FADH2: reduced FAD; Fe-S: iron-sulfur cluster; Q: coenzyme-Q or Ubiquinone; QH2: ubiquinol; SDHA: succinate dehydrogenase subunit A; SDHB: succinate dehydrogenase subunit B; SDHC: succinate dehydrogenase subunit C; SDHD: succinate dehydrogenase subunit D. *: the presumed inhibitory activity of itaconic acid. **: The presumed inhibitory activity of atpenin A5. (B) HeatMap: visualization of changes in metabolite concentrations in PC12 cell line after Sdhb knockdown, itaconate and atpenin treatment. Fold-changes of different metabolic concentration were calculated (values measured after treatment were divided with control values) then the given values were $\log 2$ transformed. These values were used for construction of the heatmap and represented with color scale (red+/white 0/green-). (C) Normalized glutamate concentrations in PC12 cells after Sdhb knockdown, itaconate and atpenin treatment, and vehicle treatments. (D) Normalized lactate concentrations in PC12 cells after Sdhb knockdown, itaconate and atpenin treatment, and vehicle treatments. atp24: $24 \mathrm{~h}$ atpenin treatment; atp48: $48 \mathrm{~h}$ atpenin treatment; ita24: $24 \mathrm{~h}$ itaconate treatment; ita48: $48 \mathrm{~h}$ itaconate treatment; siSDHB: Sdhb knockdown; SUC: succinate; LAC: lactate; PYR: pyruvate; CIT: citrate; MAL: malate; FUM: fumarate; GLU: glutamate; ASP: aspartate. *: $p<0.05 ;{ }^{* *}: p<0.01{ }^{* * * *}: p<0.0001$.

Contrary to PC12 cells, glutamate $(p=0.004)$ and lactate $(p=0.013)$ concentrations significantly increased in HeLa cells treated with itaconic acid compared to vehicle treatment after $24 \mathrm{~h}$ incubation. Elevation of both glutamate $(p<0.0001)$ and lactate $(p=0.018)$ concentrations were also significant after $48 \mathrm{~h}$ incubation (Figure S4A and Table S1).

Atpenin treatment resulted in a significant decrease in the glutamate concentrations of HeLa cells after $24 \mathrm{~h}(p<0.0001)$ and $48 \mathrm{~h}(p<0.0001)$ accompanied by significant increases in lactate concentrations after $24 \mathrm{~h}(p=0.0039)$ and $48 \mathrm{~h}(p<0.0001)$ (Figure S4A and Table S2). 
In H295R cells itaconic acid treatment caused significant increase in intracellular glutamate $(p=0.018)$ and lactate $(p<0.0001)$ levels only after $24 \mathrm{~h}$ (Figure S4B and Table S1). Glutamate concentrations significantly decreased in H295R cells after $24 \mathrm{~h}(p<0.0001)$ and $48 \mathrm{~h}(p<0.0001)$ atpenin treatment accompanied by significant increases in lactate concentrations after $24 \mathrm{~h}(p<0.0001)$ and $48 \mathrm{~h}(p=0.004)$ (Figure S4B and Table S2).

\subsubsection{GLS-1 Gene Expression was Cell Line and SDH Inhibitory Method Dependent}

Based on the metabolomics and cell viability measurements we sought to assess the importance of glutamine/glutamate metabolism, especially the mitochondrial uptake of glutamine by glutaminase-1 (GLS-1). A significant increase in GLS-1 expression after Sdhb knockout (fold change: $1.53 \pm 0.3$, $p=0.002)$ was observed in PC12 cells A significant increase in GLS-1 expression was observed after itaconate treatment of PC12 cells after $24 \mathrm{~h}$ (fold change: $1.2 \pm 0.03, p=0.015$ ) and $48 \mathrm{~h}$ (fold change $1.48 \pm 0.13, p=0.002)$. On the contrary, GLS-1 expression decreased after atpenin treatment in PC12 cells after $24 \mathrm{~h}$ (fold change: $0.89 \pm 0.1, p=0.065$ ) and significant decrease was observed after $48 \mathrm{~h}$ (fold change: $0.82 \pm 0.09, p=0.002$ ) (Figure $5 \mathrm{~A}$ ).

A

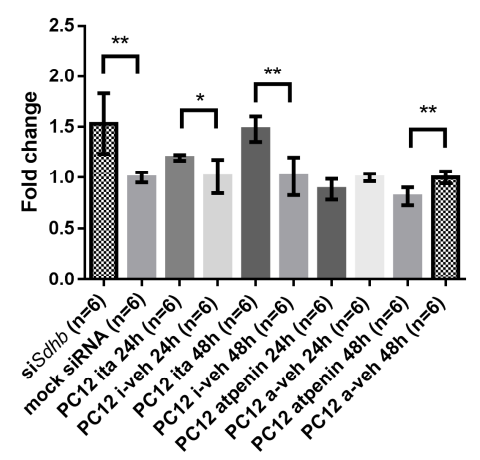

B

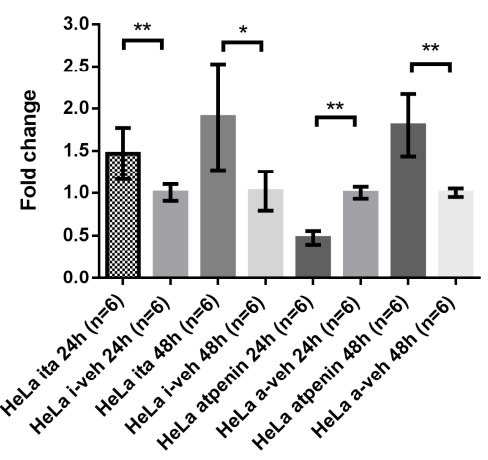

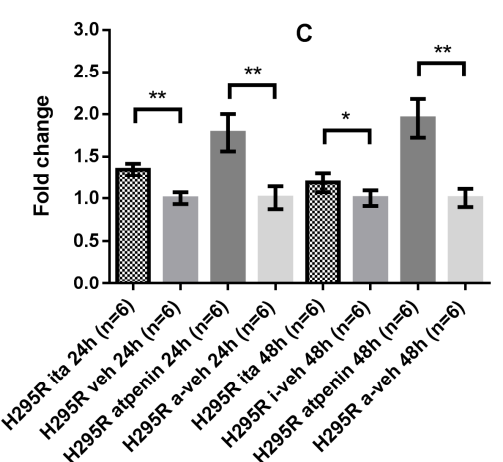

Figure 5. Glutaminase-1 (GLS-1) expression of PC12 and HeLa cells upon SDH inhibition: all values are normalized to control. (A) Fold changes in GLS-1 expression in PC12 cells upon Sdhb knockdown, itaconate treatment, and atpenin treatment. (B) Fold changes in GLS-1 expression in HeLa cells upon itaconate and atpenin treatment. (C) Fold changes in GLS-1 expression in H295R cells upon itaconate and atpenin treatment. Ita: itaconate; i-veh: control for itaconate experiments; a-veh: control for atpenin experiments; ${ }^{*}: p<0.05 ; * *: p<0.01$.

HeLa cells expressed a similar phenotype upon itaconate treatment: significant increase in GLS-1 expression was observed after $24 \mathrm{~h}$ (fold change: $1.47 \pm 0.3, p=0.002$ ) and $48 \mathrm{~h}$ (fold change: $1.9 \pm 0.63$, $p=0.015)$ treatments. On the other hand, GLS-1 expression significantly decreased after $24 \mathrm{~h}$ atpenin treatment in HeLa cells (fold change: $0.47 \pm 0.08, p=0.002$ ), but significantly increased after $48 \mathrm{~h}$ (fold change: $1.8 \pm 0.37, p=0.002$ ) (Figure $5 \mathrm{~B}$ ).

H295R cells exhibited also a significant increase in GLS-1 expression after $24 \mathrm{~h}$ (fold change: $1.34 \pm 0.1, p=0.0022$ ) and $48 \mathrm{~h}$ (fold change: $1.19 \pm 0.1, p=0.0152$ ) itaconate treatment. Atpenin significantly increased GLS-1 expression both at $24 \mathrm{~h}$ (fold change: $1.78 \pm 0.2, p=0.0022$ ) and $48 \mathrm{~h}$ $(1.95 \pm 0.2, p=0.0022)$ (Figure 5C).

2.4.5. Immunohistochemistry of SDHB and GLS-1 in Pheo/PGL Tissues Points to the Importance of GLS-1 Enzyme

Based on our in vitro findings we sought to evaluate the expression level of GLS-1 in Pheo/PGLs tumor tissues in order to assess whether GLS-1 expression might serve as a marker for malignancy in Pheo/PGLs.

Low (H-score < 100) SDHB staining characteristic for SDH-associated tumors was confirmed in all $S D H B$-associated tumor tissues while a high $(\mathrm{H}$-score $\geq 100)$ staining was observed in RET-mutant 
tumors. Both high and low SDHB staining scores were observed in the sporadic tumor group (Table 1 and Figure 6).

Table 1. Immunohistochemical evaluation of expression of SDHB and GLS-1 in Pheo/PGL tumor samples.

\begin{tabular}{|c|c|c|c|c|c|c|}
\hline \multirow{2}{*}{ Nr. } & \multirow{2}{*}{ Type of Tumor Tissue } & \multirow{2}{*}{ Biological Behavior } & \multirow{2}{*}{ Germline Mutation } & \multirow{2}{*}{ Age at Surgery Years } & \multirow{2}{*}{$\begin{array}{c}\text { SDHB } \\
\text { H-Score }\end{array}$} & \multirow{2}{*}{$\begin{array}{c}\text { GLS-1 } \\
\text { H-Score }\end{array}$} \\
\hline & & & & & & \\
\hline 1 & PGL & Malignant & \multirow{2}{*}{ SDHB p.C243Y } & 32 & 0 & 15 \\
\hline 2 & PGL & Malignant & & 34 & 65 & 150 \\
\hline 3 & PGL & Malignant & SDHB p.C196G & 32 & 10 & 160 \\
\hline 4 & Pheo & Malignant* & \multirow{2}{*}{$\begin{array}{l}\text { SDHB p.T88I and R90 } \\
\text { frame shift }\end{array}$} & 14 & 90 & 110 \\
\hline 5 & Pheo & & & 15 & 70 & 130 \\
\hline 6 & Pheo & Malignant Benign & \multirow{4}{*}{ RET p.C634R } & 18 & 160 & 0 \\
\hline 7 & Pheo & Malignant & & 21 & 155 & 5 \\
\hline 8 & Pheo & Malignant & & 22 & 210 & 10 \\
\hline 9 & Pheo & Malignant & & 25 & 150 & 110 \\
\hline 10 & Pheo & Benign & \multirow[b]{2}{*}{ RET p.C634W } & 31 & 123 & 37 \\
\hline 11 & Pheo & Malignant & & 34 & 190 & 160 \\
\hline 12 & Pheo & Benign (bilateral) & RET p.C634R & 46 & 200 & 240 \\
\hline 13 & Pheo & Benign & RET p.C634Y & 34 & 115 & 20 \\
\hline 14 & Pheo & Benign & RET p.C609S & 42 & 100 & 10 \\
\hline 15 & Pheo & Benign & RET p.C634Y & 63 & 157 & 7 \\
\hline 16 & Pheo & Benign & sporadic & 49 & 110 & 10 \\
\hline 17 & Pheo & Malignant & sporadic & 56 & 80 & 20 \\
\hline 18 & Pheo & Benign & sporadic & 47 & 140 & 120 \\
\hline 19 & Pheo & Benign & sporadic & 27 & 30 & 55 \\
\hline 20 & PGL & Malignant & SDHB c.424-1G >A & 54 & 0 & 40 \\
\hline 21 & Pheo & Benign & sporadic & 62 & 180 & 95 \\
\hline 22 & PGL & Malignant & sporadic & 82 & 160 & 10 \\
\hline 23 & Pheo & Malignant & sporadic & 18 & 120 & 10 \\
\hline 24 & Pheo & Benign & sporadic & 55 & 90 & 105 \\
\hline 25 & Pheo & Benign & sporadic & 56 & 110 & 10 \\
\hline 26 & PGL & Benign & sporadic & 30 & 10 & 135 \\
\hline 27 & Pheo & Benign & sporadic & 41 & 115 & 10 \\
\hline 28 & Pheo & Benign & sporadic & 79 & 110 & 5 \\
\hline 29 & Pheo & Benign & sporadic & 53 & 200 & 105 \\
\hline 30 & Pheo & Benign & sporadic & 43 & 180 & 20 \\
\hline 31 & Pheo & Benign & sporadic & 71 & - & 90 \\
\hline 32 & Pheo & Benign & SDHB p.Q109X & 47 & 10 & 10 \\
\hline 33 & Pheo & Benign & sporadic & 54 & 190 & 20 \\
\hline 34 & Pheo & Benign & sporadic & 65 & 140 & 30 \\
\hline 35 & Pheo & Benign & sporadic & 59 & 90 & 115 \\
\hline
\end{tabular}

Increased GLS-1 expression was detected in SDHB-mutant tumor tissues compared to RET-mutant and sporadic tumors, however the difference was not significant (H-score: $87.8 \pm 64$ vs. $59 \pm 82.4$ SDHB-mutant vs. RET-mutant, $p=0.22$; H-score: $87.8 \pm 26$ vs. $53.6 \pm 47.8$, SDHB-mutant versus sporadic, $p=0.15$ ). A total of $54 \%$ (7 of 13) of the low SDHB expressing tumors showed high GLS-1 staining while only $22 \%$ (five of 22) of high SDHB expressing tumors showed high GLS-1 staining ( $p=0.07$ ).

GLS-1 was overexpressed in three RET-mutant samples. Of these three samples, in two cases malignancy was proved as they were reoccurring, invasive, and metastatic Pheos of Patient No. 4 
(Figure 7) and Patient No. 5. The third GLS-1 overexpressing RET-mutant Pheo sample was obtained from a patient with MEN2A syndrome with bilateral Pheo (Patient No. 6, the GLS-1 positive sample was the Pheo removed from right side).

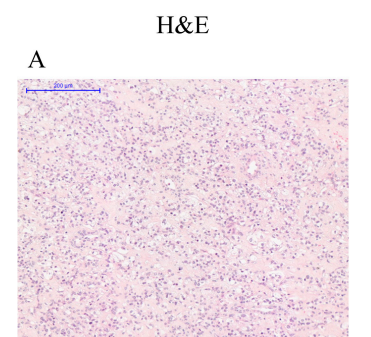

$\mathrm{D}$

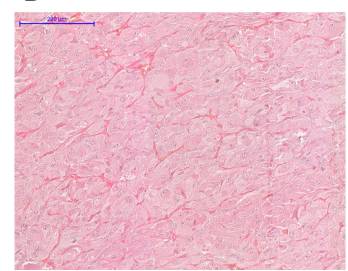

SDHB

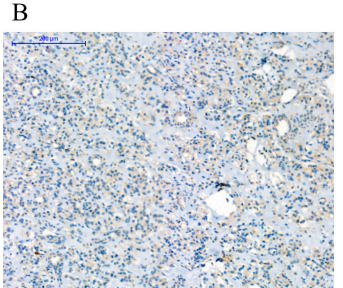

E

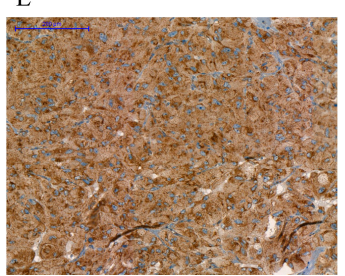

GLS-1

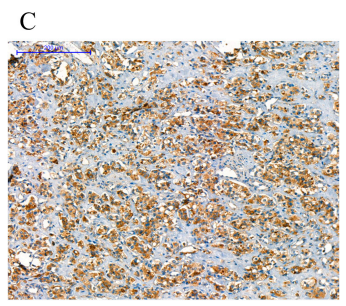

$\mathrm{F}$

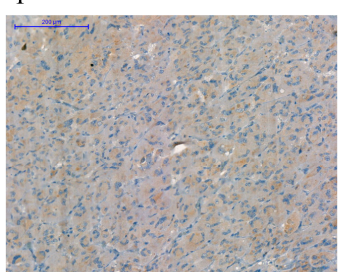

Figure 6. Immunohistochemistry: Immunostaining with antibodies against SDHB and GLS-1 of a paraganglioma associated with $S D H B$ p. mutation $(\mathbf{A}-\mathbf{C})$ and a $R E T$ p.C634W-associated pheochromocytoma (D-F). Lack of SDHB staining in SDHB mutated tumors (B) and strong GLS-1 signal was detected in malignant $S D H B$-associated tumor (C). Lack of GLS-1 positive cells can be observed in RET-associated benign pheochromocytoma (F). Scale bar $=200 \mu \mathrm{m}$. H\&E: hematoxylin and eosin staining. SDHB: succinate dehydrogenase subunit B staining. GLS-1: glutaminase-1 staining.
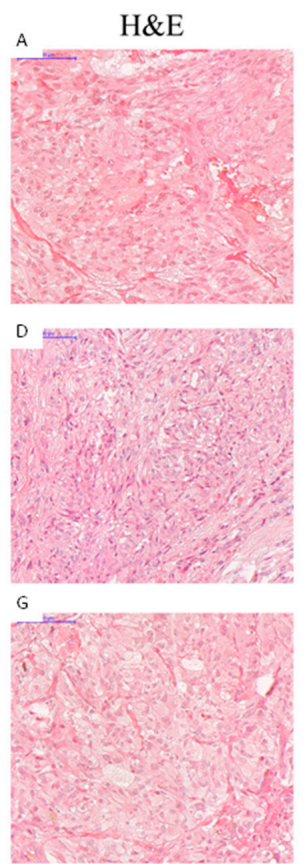
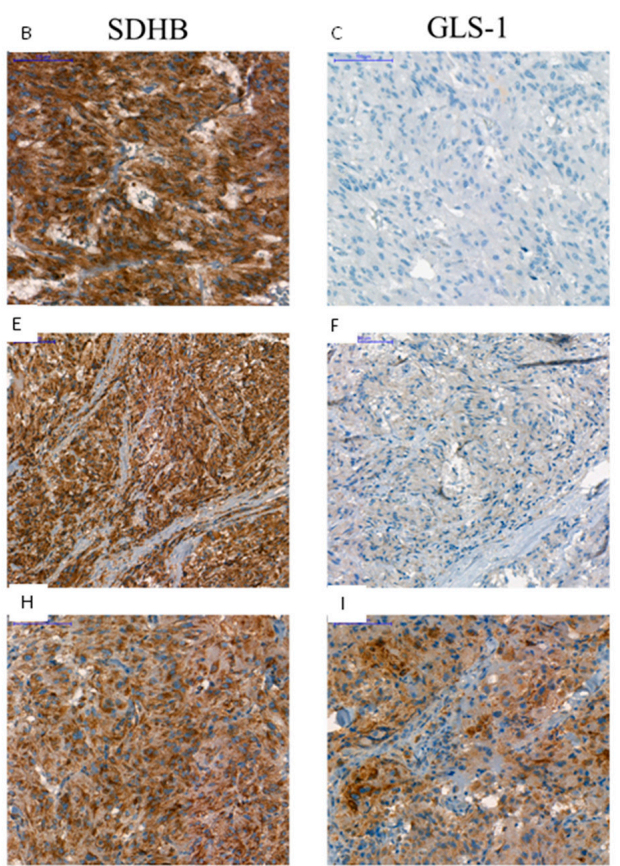

Figure 7. Immunostaining with antibodies against SDHB and GLS-1 of a RET p.C634R-associated pheochromocytoma. Panel A, D, G shows the hematoxylin and eosin stains of the primary tumor (A), the first reoccurring tumor (D) and the second reoccurring tumor $(\mathbf{G})$. Strong SDHB staining $(\mathbf{B}, \mathbf{E}, \mathbf{H})$ and lack of GLS-1 positive cells can be observed in a primary benign tumor (C). Slightly visible GLS-1 staining can be observed in the first reoccurring, invasive tumor (F) while strong GLS-1 signal was detected in the second reoccurring, invasive tumor (I). Scale bar $=100 \mu \mathrm{m}$. H\&E: hematoxylin and eosin staining. SDHB: succinate dehydrogenase subunit B staining. GLS-1: glutaminase-1 staining. 
In the three malignant sporadic Pheo/PGL samples, two showed high SDHB staining scores. All malignant sporadic samples showed low or average GLS-1 immunostaining. In case of the benign sporadic samples, out of the four samples with low SDHB scores two were accompanied by high GLS-1 immunostaining scores (Table 1).

2.4.6. GLS-1 Inhibition in PC12 Cells Decreased Proliferation after SDH Inhibition Measured by SRB Assay

The proliferation of PC12 cells was not significantly different upon SDH impairment, compared to controls (Figure 2D-F).

To test whether SDH impaired PC12 cells' proliferation is dependent on GLS-1 activity, we assessed the proliferation of the cells after BPTES treatment (BPTES is a selective GLS-1 inhibitor). Proliferation of PC12 cells significantly decreased when SDH inhibition was accompanied with BPTES treatment regardless of inhibitory methods (siRNA against $S d h b$ silenced cells after $72 \mathrm{~h}: p=0.009$; itaconate after $48 \mathrm{~h}: p=0.009$ and $72 \mathrm{~h}: p=0.009$; atpenin after $48 \mathrm{~h}: p=0.009$ and $72 \mathrm{~h} p=0.002$ (Figure 8A-C).

A

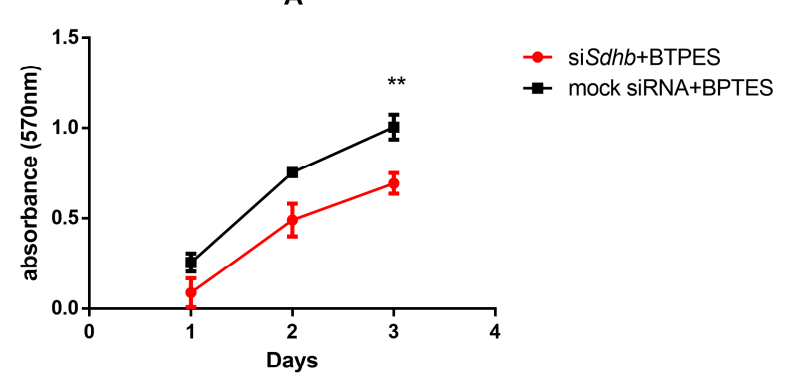

B

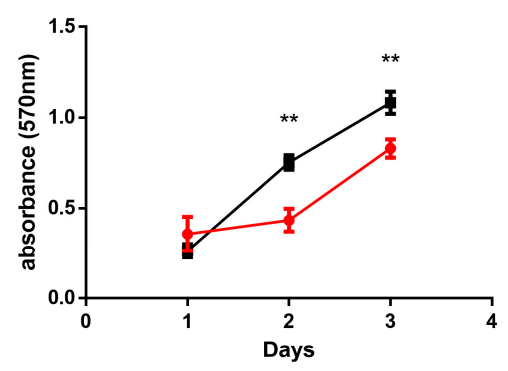

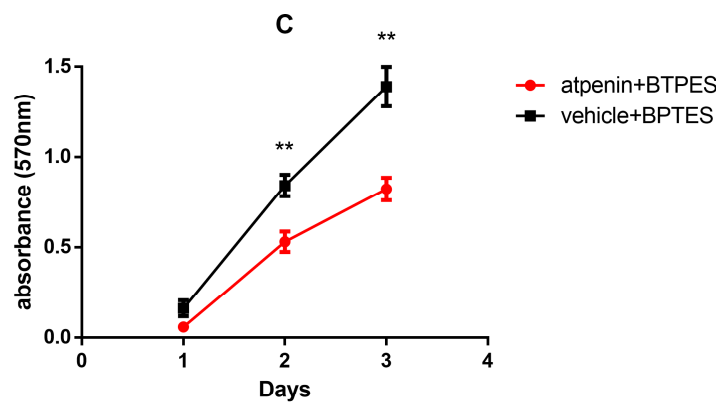

D

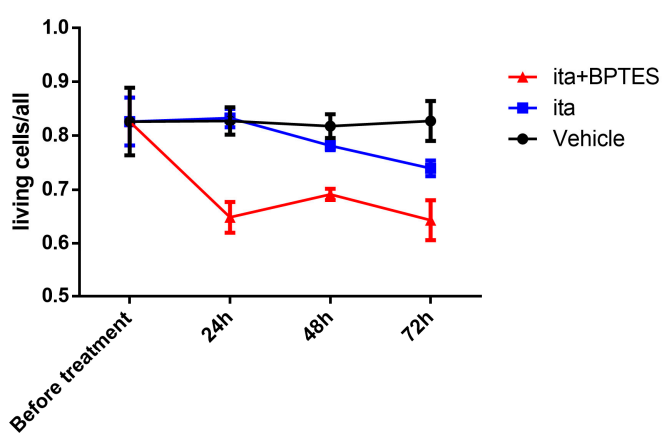

Figure 8. Proliferation of SDH impaired PC12 cells upon BPTES treatment. Cell proliferation was assessed by SRB assay. (A-C) Effects of SDH impairment and BPTES treatment on cell proliferation of PC12 cells cultured in monolayer. Experiments were performed in hexuplicates. (D) The effects of itaconate and BPTES treatment in PC12 spheroid cell culture. The ratio of living cells to total number of cells is shown before treatment and after 24,48 , and $72 \mathrm{~h}$ incubation. All experiments were performed at least six times in each group. Values are shown as mean \pm standard error mean. SRB: Sulforhodamine B; BPTES: bis-2-(5-phenylacetamido-1,2,4-thiadiazol-2-yl)ethyl sulfide; ITA: itaconate; ${ }^{* *}: p<0.01$.

2.4.7. GLS-1 Inhibition in Itaconate Treated 3D Cultured PC12 Cells Increased the Number of Dead Cells Compared to Vehicle Treated Cells

In order to assess GLS-1 inhibition in a more relevant in vitro model, we applied 3D culturing of PC12 cells by spheroid induction using spheroid inducing media. Itaconate treatment alone did not exert a significant effect on the ratio of living cells (compared to vehicle treatment 3\% and $9 \%$ after 48 and $72 \mathrm{~h}$ treatment, respectively). When itaconate was accompanied by BPTES treatment in the 3D 
cultured PC12 cells, $18 \%, 13 \%$, and $18 \%$ decreases were observed in the living cell ratios compared to vehicle treatment at 24,48 , and $72 \mathrm{~h}$, respectively ( $p<0.0001$ for each comparison) (Figure $8 \mathrm{D}$ ).

\subsubsection{Oxygen Consumption Rate Measurements}

After biochemical characterization of SDH inhibition we assessed the mitochondrial respiration upon SDH inhibition using SeaHorse measurements in PC12 cells (Figure 9A). The effects of Sdhb knockdown were compared to mock transfected cells whereas the consequences of itaconate and atpenin treatment were compared to control (untreated) PC12 cells.

Basal respiration is derived by the subtraction of non-mitochondrial respiration from the baseline respiration. BPTES treated control cells yielded the lowest basal oxygen consumption ratio (OCR), whereas itaconate the highest. Compared to control PC12 cells, itaconate yielded a significantly higher basal respiration $(p=0.007)$ whereas $S d h b$ knockdown resulted in significantly lower basal respiration rate compared to mock transfected cells $(p=0.0079)$. BPTES treatment of cells transfected with siRNA against $S d h b$ or mock transfection did not result in a significant difference in OCR values (Figure 9B).

Basal respiration was then evaluated after administration of $2 \mathrm{mM}$ glutamine. Only minor changes were observed in itaconate $(1.4 \%)$, atpenin $(1.7 \%)$, and $S d h b$ silenced cells $(0.5 \%)$. BPTES treatment only had a significant effect on $S d h b$ silenced cells when their basal oxygen consumption was compared to the OCR after glutamine admission $(p=0.0079)$. Similarly, a significant difference $(p=0.0079)$ was observed when the OCR of $S d h b$ silenced cells were compared to mock transfected cells after glutamine admission. BPTES treated Sdhb silenced and mock transfected cells' OCRs after glutamine admission did not differ significantly $(p=0.15)$.

Maximal respiration is defined as the difference of OCR after 2,4-dinitrophenol (DNP) and after antimycin $\mathrm{A}+$ rotetone $(\mathrm{A}+\mathrm{R})$ admission. Itaconate treatment and siSdhb knockdown significantly increased maximal respiration $(p=0.0079)$. BPTES treatment significantly reduced the maximal OCR of both control $(p=0.0079)$ and siSdhb silenced $(p=0.0079)$ PC12 cells (Figure 9C).

Non-mitochondrial respiration is displayed after inhibition both of complex I and complex III with A+R. PC12 cells transfected with siRNA against $S d h b$ had the highest non-mitochondrial respiration which did not decrease significantly after BPTES treatment. Both itaconate $(p=0.0159)$ and siSdhb treatment $(p=0.0079)$ significantly increased the non-mitochondrial respiration of PC12 cells (Figure 9D). 


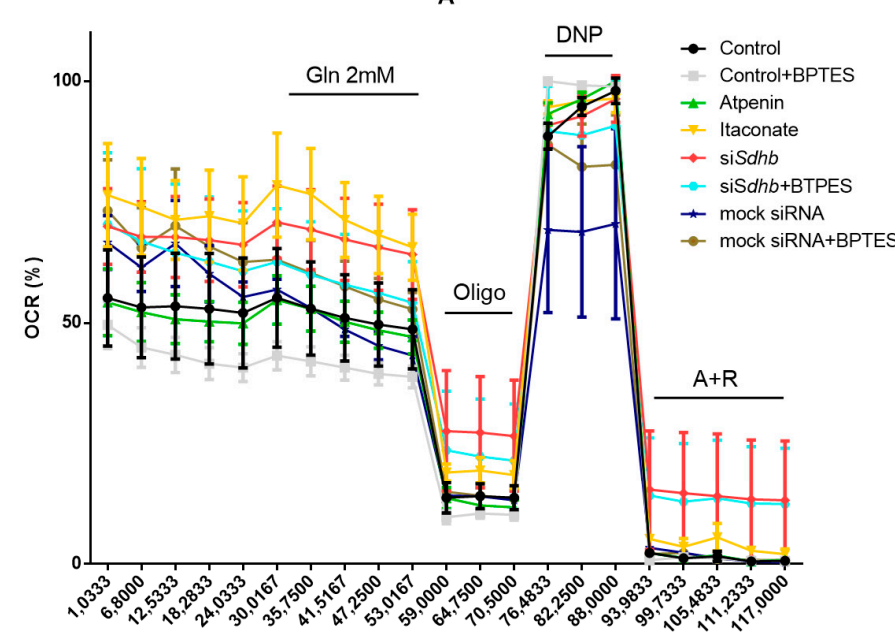

Time (min)

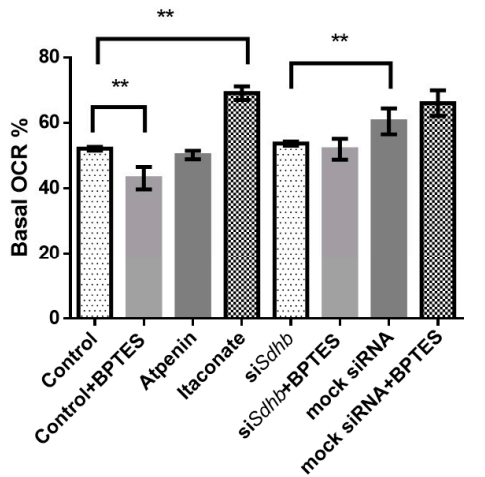

C

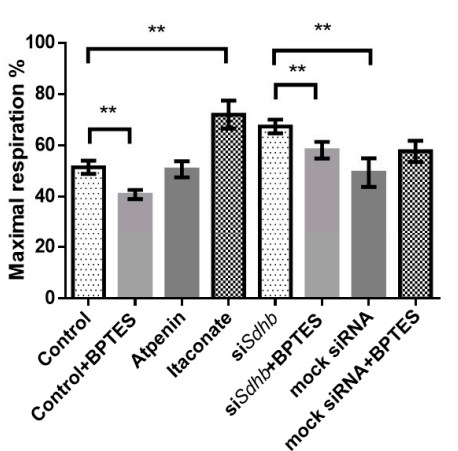

Figure 9. Oxygen consumption measurements of PC12 cells. (A). Oxygen consumption ratio (OCR \%) of PC12 cells. The minimum value of OCR is $0 \%$, maximum is $100 \%$. (B) Basal respiration: subtraction of non-mitochondrial respiration from the baseline respiration. (C). Maximal respiration of PC12 cells: difference of OCR after 2,4-dinitrophenol (DNP) and after antimycin A + rotetone $(A+R)$ admission. (D) Non-mitochondrial respiration: OCR after inhibition of both complexes I and III with A + R. OCR: oxygen consumption ratio; Gln: glutamine; Oligo: oligomycin; DNP: 2,4-dinitrophenol; A + R: antimycin A + rotetone. ${ }^{*}: p<0.05 ;{ }^{* *}: p<0.01$. 


\section{Discussion}

Pheo/PGLs present a genetically heterogenic tumor group, arising from the adrenal medulla or the extra-adrenal paraganglia. A total of $40 \%$ of these neuro-endocrine tumors are inherited in an autosomal dominant manner due to mutations in one of the 17 Pheo/PGL-associated genes [48,49]. Of these genes, seven (SDHA, SHDAF2, SDHB, SDHC, SDHD, FH, MDH2) encode enzymes participating in the TCA cycle. Mutations of the $S D H B$ gene represent a strong susceptibility for malignancy [50-53]. The precise pathomechanism behind the $S D H x$ mutations and especially the malignant potential of $S D H B$ mutations is still unknown despite the several observations made through the last decades [54-56]. Unfortunately, there is no therapeutic option for malignant cases which warrants further studies to identify novel therapeutic targets. Several novel approaches were introduced recently to address the lack of therapeutic options: the inhibition of glutathione synthesis was shown to contribute to the DNA damage as a result of the increased level of reactive oxygen species in $S D H B$ mutant tumors [57]. Inhibition of complex I made complex II impaired tumors more sensitive to DNA damaging chemotherapeutic agents [58] while it has been also demonstrated that elevated succinate and fumarate levels suppress the homologous recombination DNA pathway, rendering these tumors vulnerable to poly(ADP)-ribose polymerase inhibitors [59]. In addition to the lack of therapeutic options, prognostic factors for the prediction of malignant disease are also mandatory for establishing a proper strategy for the management of the disease. However, previous attempts show that creating a universal prognostic factor for all etiologies of Pheo/PGL is hardly possible [60].

The succinate accumulation in SDHx mutant tumors can inhibit the $\alpha$-ketoglutarate-dependent prolyl hydroxylases, which have an important role in the degradation of HIF1 $\alpha$ and HIF $2 \alpha$ under normoxia [12]. Mutations in the SDHB subunit beside the HIF1 $\alpha$ stabilization, shift the cellular metabolism towards reductive glutamine catabolism [61]. Recently, Lorendeau et al. reported that both loss of complex I and complex II activity are necessary to mimic the metabolic phenotype of $S D H$ mutant tumors based on reductive glutamine metabolism, sole SDHA or SDHB inhibition failed to do so in their study [62]. Our aim was to assess the consequences of SDH impairment in various cell types and to search for novel in vitro models, prognostic markers, and therapeutic targets for tumors with reduced or absent $\mathrm{SDH}$ activity.

Knockdown of $S d h b$ with siRNA in PC12 rat chromaffin cells successfully inhibited SDH activity and increased succinate/fumarate ratio by $>3$ fold compared to mock siRNA transfected cells. Increased succinate to fumarate ratio also characteristic for SDH mutant Pheo/PGLs [63]. Based on the metabolite measurements, both itaconate and atpenin were more potent SDH inhibitors than Sdhb knockdown.

Based on the cell viability and oxygen consumption measurements, PC12 cells were not affected negatively by SDH impairment. Moreover, these cells showed an overall positive response to SDH impairment while HeLa and H295R cells showed decreased viability after itaconate treatment. Atpenin also increased HeLa cell line viability, whereas decreased H295R cell line viability. Based on these data we assume that the impairment of SDH activity (either by itaconate or atpenin treatments or Sdhb knockdown) has a cell type-specific effect on the viability of cells. Significant difference in PC12 cells' proliferation was not observed after SDH impairment in monolayer cell culture. Itaconate treatment of the 3D PC12 cell culture model did not decrease the ratio of living cells significantly. Based on these results we conclude that PC12 cells can cope with SDH impairment both in the monolayer and the 3D cell culture model.

Next, we sought to evaluate whether the cell viability effects can be traced back to the differences in the metabolite profiles observed after SDH inhibition (beside the differences in the succinate/fumarate ratios). In general, inhibition of SDH shifts cellular metabolism to anaerobic glycolysis, and administration of itaconate is also associated with lactate accumulation [64]. However, in contrary to HeLa and H295R cell lines, the expected increase in lactate concentrations was absent in PC12 cells after itaconate treatment and after $S d h b$ knockout. Sdhb knockdown significantly decreased glutamate concentrations which is in line with the data demonstrating that SDHx mutant tumors also 
accumulate lower levels of glutamate [33], and SDHB mutation associated with increased glutamine metabolism [35].

In addition, glutamine was shown to be the main source in SDHB-mutated UOK269 cells and this metabolite linked HIF-1 $\alpha$ stabilization and DNA methylator phenotype [61].

Pursuing the role of glutamine in SDH impaired cells we studied the respiration of SDH impaired PC12 cells. These cells in the presence of glutamine effectively switch from glycolysis to glutaminolysis which increases the basal OCR values. These results are in line with the data published by Zhdanov et al., who showed that increase in the OCR values upon mitochondrial uncoupling was only seen when glutamine was combined with either glucose or pyruvate. In addition, the cell-specific dependence on glutaminolysis was also highlighted [23]. Itaconate but not atpenin had the same effect, it increased the basal respiration of PC12 cells whereas it did not have a significant impact on lactate concentration further supporting its capability to serve as a model for $S d h b$ mutant Pheo/PGLs.

The most significant effect related to oxygen consumption was observed in the non-mitochondrial respiration fraction, suggesting that these cells use non-mitochondrial respiration for survival. In pheochromocytoma and paragangliomas there is no data about the expression and role of mitochondrial uncoupling protein 2 (UCP2) which has been suggested to be a metabolic sensor of cells under nutrient shortage. We may hypothesize that in SDH deficient cells a rapid metabolic adaptation occurs which allows these cells to survive by either shifting its metabolism to the use of the alternative fuel glutamine or going into a reversible, more quiescent state [65].

Glutamate has an extensive role in cell metabolism [66] and disruption of the TCA cycle makes the cells more dependent on reductive carboxylation of glutamine instead of the oxidative metabolism of the TCA cycle [67-69]. GLS-1 is a mitochondrial enzyme that generates glutamate from glutamine, which further metabolizes to aspartate and $\alpha$-ketoglutarate in the mitochondria. GLS-1 has been found to be upregulated in some cancers, and in some cases deregulated glutamine metabolism is essential for cancer growth [29-32].

Therefore, we sought to assess the expression of GLS-1 in vitro after SDH impairment. PC12 cells exhibited significantly increased GLS-1 expression upon Sdhb knockdown and SDH inhibition with itaconate too. Interestingly, atpenin treatment decreased the expression of GLS-1 in PC12 cells. HeLa cells also exhibited a significant increase in GLS-1 expression upon itaconate treatment. Similar to the PC12 cell line, atpenin treatment resulted in significantly decreased GLS-1 expression after $24 \mathrm{~h}$ in HeLa cells. However, this was reversed after 48 h, when a significant increase in GLS-1 expression was observed. The H295R cell line also displayed significantly increased GLS-1 expression after SDH inhibition by either itaconate or atpenin. These results indicate that SDH inhibition exhibits cell line and inhibitory method specific consequences and the dynamism of metabolic changes varies among cell types, but in PC12 cells both Sdhb knockdown and itaconate treatment increased its expression suggesting that these cells might be dependent on this enzyme. Contrary, in HeLa and H295R cells, increased GLS-1 expression was not necessarily associated with decreased glutamate concentrations. We hypothesize that even though the entry for glutamate is enhanced by the increased GLS-1 expression, glutamate is not used effectively after itaconate treatment in these cells which further emphasizes the importance of appropriate selection of in vitro models. In addition, further studies are warranted to clarify the role of GLS-1 in these cancer cells.

Based on these observations we evaluated the dependence on GLS-1 function of PC12 cells with impaired SDH activity. When SDH inhibition was accompanied by selective GLS-1 inhibition, PC12 cells showed significantly decreased proliferation in monolayer cell culture. Increased cell death was observed in the 3D PC12 cell culture model, suggesting that chromaffin cells with SDH impairment are dependent on the GLS-1 enzyme. It has to be mentioned that currently there is an ongoing clinical trial with the GLS-1 inhibitor CB-839 for SDH-associated gastrointestinal stromal tumors and non-gastrointestinal stromal tumors. However, an earlier study performed in pancreatic cancer showed the limited clinical efficacy of CB-839 monotherapy [70] which highlights again that various GLS-1 inhibitors may cause significantly different effects on chromaffin cells' proliferation. 
In order to translate our in vitro data to clinics we examined for the first time the expression of GLS-1 in various Pheo/PGL tumor tissues with known genetic background by immunohistochemistry. In line with in vitro data our immunohistochemistry analysis demonstrated an increased GLS-1 staining in SDHB-low expressed tumors compared to tumors with intact SDHB protein. Furthermore, a significant proportion of $S D H B$ - and RET-associated malignant tumors also showed an increase in GLS-1 staining compared to benign RET-associated and sporadic tumors. It should be also mentioned that in some cases increased GLS-1 expression was not associated with malignancy. On the other hand, determination of malignancy in Pheo is difficult, because there is no obvious marker for it. Several studies, including a study published by Stenman et al., showed that even in RET-associated Pheos, using the "Pheochromocytoma of the Adrenal Gland Scaled Score "(PASS) and "Grading System for Adrenal Pheochromocytoma and Paraganglioma" (GAPP) algorithms, the malignancy was over-diagnosed [60]. In our study we considered a Pheo malignant when the tumor was recurring, or local or distal metastases were detected. In our in vitro experiments, the increased GLS-1 expression was not necessarily associated with increased viability, suggesting that for increased proliferation, other factors are also needed. The importance of GLS-1 may be the most important in SDH-compromised cells, where the concomitant inhibition of SDH and GLS-1 could result in cell lethality. The heterogeneous phenotype associated with $S d h b$ mutations is highlighted in an in vivo model of $S d h b$ mutation developed in Caenorhabditis elegans, where the deleted mutant arrested in development, while the point mutant form was viable and it presented only infertility [71]. This further supports personalized and case specific treatment of the disease.

In conclusion, we assume that GLS-1 contributes to SDHB-mutant malignant tumor growth and we presume that the evaluation of GLS-1 expression before therapy might yield valuable information for the management of the disease. A larger study evaluating malignant and benign Pheo/PGLs with various genetic backgrounds would clarify this observation and would decipher to role of GLS-1 in Pheo/PGL cells.

\section{Materials and Methods}

All materials were purchased from Merck-Sigma-Aldrich (Darmstadt, Germany), except where it is indicated in the text.

\subsection{Cell Lines}

All cell lines were obtained from American Type Culture Collection (ATCC). Cell cultures were incubated at $37^{\circ} \mathrm{C}$ in a humidified $5 \% \mathrm{CO}_{2} / 95 \%$ air atmosphere.

PC12 cells (rat pheochromocytoma cell line) were grown in 75- $\mathrm{cm}^{2}$ flasks in F-12 (\# 21127022 F-12 Kaigh's modification, Gibco, Thermo Fisher Scientific, Waltham, MA, USA), containing 15\% horse serum (Gibco BRL), 5\% fetal bovine serum (Gibco BRL), and 1\% penicillin-streptomycin (Biosera LM-A4118/100). Culture media was replaced three times a week. Cells were removed from flasks for subculture and for plating into assay dishes using Trypsin-EDTA solution.

HeLa cells (human cervix carcinoma cell line) were grown in $75-\mathrm{cm}^{2}$ flasks in Dulbecco's modified Eagle medium/HamF12 (DMEM/F12) (\#11330032, Thermo Fisher Scientific, Waltham, MA, USA) containing 10\% FBS (\#10270106, Thermo Fisher Scientific, Waltham, MA, USA) and $1 \%$ penicillin-streptomycin (LM-A4118/100, Biosera, Nouille, France). Culture media was replaced three times a week. Cells were removed from flasks for subculture and for plating into assay dishes using Trypsin-EDTA solution.

H295R cells (human adrenocortical carcinoma) were grown in 75- $\mathrm{cm}^{2}$ flasks in Dulbecco's modified Eagle medium/HamF12 (DMEM/F12) containing HEPES buffer, L-glutamine, and pyridoxine $\mathrm{HCl}$ (\#11330032, Thermo Fisher Scientific, Waltham, MA, USA). Additional supplements were added to the medium, including $0.00625 \mathrm{mg} / \mathrm{mL}$ insulin (\#I9278, Sigma, St. Louis, MO, USA), 0,00625 mg/mL human transferrin (\#T5391, Sigma, St. Louis, MO, USA), and $6.25 \mathrm{ng} / \mathrm{mL}$ selenous acid (\#S9133, Sigma, St. Louis, MO, USA) $1.25 \mathrm{mg} / \mathrm{mL}$ bovine serum albumine (\#A9647, Sigma, St. Louis, MO, USA), 2.5\% 
nu-serum (Zenon Bio Kft. Szeged, Hungary), and 1\% penicillin-streptomycin (\#P0781, Sigma, St. Louis, MO, USA).

\subsection{Sdhb Silencing Using Small Interfering RNA (siRNA)}

PC12 cells were seeded in six-well plates for $24 \mathrm{~h}$ before transfection with two Silencer Select small interfering RNAs (siRNA A: Sequence (5'-3': GAUUAAGAAUGAAAUCHAUtt, siRNA ID: \#s151576; siRNA B: Sequence (5'-3': GCAAAGUCUCGAAAAUAUAtt, siRNA ID: \#s220846) (Ambion, Thermo Fisher Scientific, Waltham, MA, USA) targeting SDHB using RNAiMAX Reagent (Invitrogen, Thermo Fisher Scientific, Waltham, MA, USA) according to the manufacturer's protocol. For negative control, cells cultured under identical conditions were transfected with non-targeting Silencer Select siRNA (Ambion by Life Technologies). Specific effect of siRNA against $S d h b$ was verified by Western blot analysis.

\subsection{Protein Extraction and Western Blot}

Total protein was extracted with M-Per reagent (\#78503, Thermo Fisher Scientific, Waltham, MA, USA), according to the manufacturer's instructions. Protein concentrations were determined by BCA Assay (Sigma, St. Louis, MO, USA). Total protein was separated by $10-15 \%$ SDS polyacrylamide gel electrophoresis, transferred to a PVDF membrane, and incubated overnight with primary antibody against SDHB (5 $\mu \mathrm{g} / \mathrm{mL}$; anti-SDHB, ab14714, Abcam, Cambridge, United Kingdom). Spectra Multicolor Broad Range Protein Ladder (\#26634, Thermo Fisher Scientific, Waltham, MA, USA) was used as a protein ladder. For loading control membranes were stripped and re-probed using mouse anti- $\beta$-actin (1:25,000, Cell Signaling Technology, ZA, Leiden, The Netherlands). Anti-mouse HRP-conjugated IgG was used as secondary antibody (1:2,000, \#P044701, Agilent, Santa Clara, CA, USA). Band intensities were quantified using Image J software (National Institutes of Health, Bethesda, MD, USA).

\subsection{Biochemical Inhibition of SDH Enzyme}

Itaconic acid was purchased from Sigma (\#I29204, Sigma-Aldrich (Sigma, St. Louis, MO, USA). The $500 \mathrm{mM}$ stock solutions were prepared with nuclease free water; $\mathrm{pH} 7.2$ was adjusted with $\mathrm{NaOH}$.

Cells were seeded onto six-well plates. After $24 \mathrm{~h}$ incubation, the used medium was replaced by fresh medium, after washing with PBS. Then, $25 \mathrm{mM}$ itaconic acid was added in the wells. Nuclease free water was used as control.

Atpenin A5 (atpenin) used for our study was a generous gift from Christos Chinopoulos. Atpenin was purchased from Enzo Life Sciences (\#ALX-380-313-MC25, Enzo Life Sciences, Inc., Farmingdale, NY, USA). First, $2 \mathrm{mM}$ stock solution was prepared with absolute ethanol. Cells were seeded onto six-well plates. After $24 \mathrm{~h}$ incubation, the used medium was replaced by fresh medium, after washing with PBS. Then, $1 \mu \mathrm{M}$ itaconic acid was added in the wells. Absolute ethanol in the same treatment volume was used as control.

\subsection{Inhibition of GLS-1 Activity}

Bis-2-(5-phenylacetamido-1,3,4-thiadiazol-2-yl) ethyl sulfide (BPTES) was purchased from Sigma (\#SML0601, Sigma-Aldrich (Sigma, St. Louis, MO, USA). The 2mM stock solutions were prepared with DMSO. Then, $10 \mu \mathrm{M}$ BPTES was added to the cells. DMSO was used as control.

\subsection{Cell Viability and Proliferation Assays}

AlamarBlue test was used (Thermo Fisher Scientific, Waltham, MA, USA) to determine the viability effects of itaconic acid and atpenin treatment after 24, 48, and $72 \mathrm{~h}$ in PC12, HeLa, and H295R cells and in PC12 cells after transfection of siRNA against $S d h b$ or mock siRNA and after co-treatment with BPTES. The assay was performed in 96-well plates. All treatments at each time point and siRNA transfections were performed in six replicates, outliers were excluded before the statistical analysis. 
For studying the viability changes with AlamarBlue assay, PC12 cells were plated in $100 \mu \mathrm{L}$ cell culture media at a density of 5000 cells/well for $24 \mathrm{~h}$ treatment, 2500 cells/well for $48 \mathrm{~h}$ treatment, and 1700 cells/well for $72 \mathrm{~h}$ treatment. HeLa cells were plated in $100 \mu \mathrm{L}$ cell culture media at a density of 3000 cells/well for $24 \mathrm{~h}$ treatment, 1500 cells/well for $48 \mathrm{~h}$ treatment, and 1000 cells/well for $72 \mathrm{~h}$ treatment. H295R cells were plated onto 96-well culture plates in $100 \mathrm{uL}$ cell culture media at a density of 10000 cells/well for $24 \mathrm{~h}$ treatment; 5000 cells/well for $48 \mathrm{~h}$ treatment; 3500 cells/well for $72 \mathrm{~h}$ treatment. After $24 \mathrm{~h}$, cell media was replaced by fresh media, and itaconate, atpenin, or siRNA against $S d h b$ treatment was performed. After the given incubation time, $10 \mu \mathrm{L}$ AlamarBlue, was added to each well. After $1 \mathrm{~h}$ and $15 \mathrm{~min}$ incubation at $37^{\circ} \mathrm{C}$, fluorescence was measured in the 560-590 $\mathrm{nm}$ range using Varioskan Flash plate reader (Thermo Fisher Scientific). Percentage of the cell proliferation was given relative to control samples.

Sulforhodamine B (SRB) assay was used for evaluation of proliferation of PC12 cells. The cells were seeded onto 96-well plates at a density of 2500 cells/well. Each measurement was performed six replicates. After incubation with the indicated drug concentrations for $24 / 48 / 72 \mathrm{~h}$, cells were fixed by cold $10 \%$ trichloroacetic acid for $60 \mathrm{~min}$ in $4{ }^{\circ} \mathrm{C}$, washed with water, and dried. After drying, cells were incubated with $0.4 \%$ sulforhodamine B (Sigma-Aldrich) for $15 \mathrm{~min}$ in RT. After washing with $1 \%$ acetic acid, the protein-bound dye was dissolved in $10 \mathrm{mM}$ Tris. The absorbance at $570 \mathrm{~nm}$ was measured in LabSystems Multiskan RC/MS/EX Microplate Reader (Artisan Scientific, Champaign, IL, USA).

\subsection{D Culturing of PC12 Cells}

The PC12 rat cell line was seeded with a density of 500,000 cells per six-well ( $2 \mathrm{~mL} / \mathrm{well})$ at $37^{\circ} \mathrm{C}$ and $5 \% \mathrm{CO}_{2}$. For spheroid induction serum-free defined media (Lichner et al. 2015) containing Ham's F-12K (Kaighn's) Medium (Gibco; Thermo Fisher Scientific) with 2\% B27 Supplement, 50 ng/mL EGF and $50 \mathrm{ng} / \mathrm{mL}$ FGF was used. After spheroid formation $(96 \mathrm{~h})$ cells were treated with $500 \mathrm{nM}$ itaconate and $10 \mu \mathrm{M}$ itaconate-BPTES solution for 24,48 , and $72 \mathrm{~h}$.

In 3D structure biochemical assays for proliferation and viability are not reliable due to uncertain diffusion of the reagent into the inner/central part of the spheroids. Therefore, viable and dead cells were investigated by trypan blue staining method. Spheres were dissociated with trypsine then they were stained with $0.4 \%(w / v)$ trypan blue solution (Life Technologies, California, CA, USA). Cell growth and the number of live and dead cells were assessed under Burker chamber.

\subsection{Measurement of the Intracellular Concentration of Metabolites Using Liquid Chromatography Mass Spectrometry (LC-MSMS)}

Cells were grown in six-well plates. All experiments (treatment with itaconic acid and siRNA transfection) were made in three replicates except for $24 \mathrm{~h}$ itaconic acid treatment of PC12 cells, where nine biological replicates were carried out.

Intracellular metabolites (lactate, pyruvate, citrate, $\alpha$-ketoglutarate, succinate, fumarate, malate, glutamate, aspartate) were extracted by a modified method based on Szoboszlai et al. [72]. In brief, the cells were quenched in liquid nitrogen and extracted by mixture of $\mathrm{MeOH}-$ chloroform- $\mathrm{H}_{2} \mathrm{O}(9: 1: 1)$ and vortexed at $4{ }^{\circ} \mathrm{C}$. After centrifugation $\left(15,000 \times g, 10 \mathrm{~min}, 4^{\circ} \mathrm{C}\right)$ the clear supernatants were kept at $-80^{\circ} \mathrm{C}$ until liquid chromatography-mass spectrometry (LC-MS) measurements. The concentrations of lactate, citrate, succinate, fumarate, malate, glutamate, and aspartate were assessed by using calibration curves obtained with the dilution of analytical grade standards in the range of $0.5-50 \mu \mathrm{M}$. LC-MS assays were used by Perkin-Elmer Flexar FX10 ultra-performance liquid chromatograph coupled with a Sciex 5500 QTRAP mass spectrometer. Chromatographic separation was carried out on a Phenomenex Luna Omega C18 column $(100 \times 2.1 \mathrm{~mm}, 1.6 \mu \mathrm{m})$ (GenLab Ltd., Budapest, Hungary). The mobile phase consisted of water and methanol containing $0.1 \%(v / v)$ formic acid. The MS was operating in negative electrospray ionization mode. For the measurements the following settings were adjusted-source temperature: $300{ }^{\circ} \mathrm{C}$ ionization voltage: $-4000 \mathrm{~V}$, entrance potential: $-10 \mathrm{~V}$, curtain gas: 35 psi, gas1: 35 psi, gas2: 35 psi, CAD gas: medium. Multiple reaction monitoring (MRM) mode was applied to 
perform quantitative analyses. All samples were measured in triplicate. Concentrations of metabolites were normalized to DNA concentration isolated from cells plated, incubated, and treated in the same manner as cells used for metabolite analysis. The cells were trypsinized and DNA was extracted using the semiautomatic DNA isolation protocol with QIAcube instrument (Qiagen, Hilden, Germany). The concentration of the extracted DNA samples was measured with NanoDrop 1000 Spectrophotometer (Thermo Fisher Scientific, Waltham, MA, USA).

\subsection{Expression of SDHB and Glutaminase Type 1 (GLS-1) in Hereditary Pheochromocytoma/Paraganglioma} Tissues Using Immunohistochemistry

Representative tissue blocks $(n=35)$ from 29 patients with Pheo/PGL were evaluated by two expert pathologists. Eleven patients had hereditary Pheo/PGLs (five carried SDHB and six patients carried the RET mutation (Table 1). Informed consent was obtained from all subjects and the experiments conformed to the principles set out in the WMA Declaration of Helsinki. Our study was approved by the Scientific and Research Committee of the Medical Research Council of Ministry of Health, Hungary (ETT-TUKEB 4457/2012/EKU).

Malignancy was diagnosed when a tumor was recurring, or local or distal metastases were detected. Of 35 tissue samples 13 were classified as malignant (six related to SDHB while four to RET mutations, no pathogenic mutations were detected in three malignant cases). Immunostaining of SDHB and GLS-1 was performed as previously described [73]. In brief, $4 \mu \mathrm{m}$-thick sections of formalin-fixed paraffin-embedded were used. After deparaffinization and blocking the endogenous peroxidases, antigen retrieval was performed for $30 \mathrm{~min}$ (10 $\mathrm{mM}$ citrate $\mathrm{pH}$ 6.0) using a pressure cooker. Slides were incubated with anti-glutaminase (ab156876, Abcam) and anti-SDHB (ab14714, Abcam) primary antibodies. Immunohistochemical reactions were visualized using Novolink Polymer (Leica Biosystems, Wetzlar, Germany) detection system and 3,3'-Diaminobenzidine (DAB, Dako) chromogen, followed by hematoxylin counterstain. Immunoreactivity was assessed in tumor cells (and normal adrenal medulla cells as control) using H-scores [74], which range from 0 to 300 and were calculated by multiplying the intensity of staining ( 0 -no staining, $1+-$ weak staining, $2+-$ moderate staining, or $3+-$ strong staining) and the percentage of immunopositive cells (0-100). For example, $40 \%$ of tumor cells staining positive with moderate intensity $(2+)$ and $10 \%$ of the tumor cells staining with strong intensity (3+) results in an H-score of 110. Based on H-score, expression of SDHB and GLS-1 was classified as 'low' (H-score < 100) and 'high' (H-score $\geq 100)$.

\subsection{GLS-1 Gene Expression Measurements}

Experiments were performed in six-well plates in duplicates for RNA isolation. Total RNA was harvested using RNeasy Mini Kit (50) (\#74104, Qiagen, Hilden, Germany), according to the manufacturer's instructions. RNA concentrations were determined with NanoDrop 1000 Spectrophotometer (Thermo Fisher Scientific, Waltham, MA, USA). For the quantitative real-time PCR (qRT-PCR) experiments, $1 \mu \mathrm{g}$ of total RNA was reverse transcribed using High-Capacity RNA-to cDNA Kit (\#4387406, Thermo Fisher Scientific, Waltham, MA, USA), according to the manufacturer's instructions. For gene expression measurements, predesigned TaqMan Gene Expression assays were used (rat GLS: Rn00561285_m1, human GLS-1: Rn00667869_m1, rat actin: Rn00667869_m1, human actin: Hs99999903_m1; all from Applied Biosystems by Life Technologies). cDNA was diluted 100×. All measurements were performed in triplicate. DeltaCT ( $\mathrm{dCT}$ ) values were calculated and deltadeltaCT $(\mathrm{ddCT})$ values were normalized to the controls in the experiments. Fold change values were calculated from $2^{-\mathrm{ddCT}}$.

\subsection{Cellular Respiration}

Seahorse XF96 Analyzer (Agilent Technologies, Santa Clara, CA, USA) was used to assess real-time oxygen consumption rate (OCR), reflecting mitochondrial oxidation and extracellular acidification rate (ECAR), based on previous descriptions $[40,75,76]$. PC12 cells were plated in $100 \mu \mathrm{L}$ complete medium 
at 30,000 cells/well density onto 96-well Seahorse plates (Agilent Technologies, Santa Clara, CA, USA) $24 \mathrm{~h}$ prior to the assays. Itaconate $(25 \mathrm{mM})$ or atpenin $(1 \mu \mathrm{M})$ treatment was carried out 24 or $48 \mathrm{~h}$ before the assays, whereas transfection with siRNA against $S d h b$ or mock vector $48 \mathrm{~h}$ before the assays. BPTES treatment was carried out $24 \mathrm{~h}$ prior to the assay. On the day of the assay complete medium was removed and was replaced by a medium containing (in $\mathrm{mM}$ ): $120 \mathrm{NaCl}, 3.5 \mathrm{KCl}, 1.3 \mathrm{CaCl}_{2}, 1.0 \mathrm{MgCl}_{2}$, 20 HEPES, 10 glucose at $\mathrm{pH}$ 7.4. The basal OCR and ECAR values were calculated after $1.5 \mathrm{~h}$ incubation at this condition.

During the measurements freshly prepared glutamine $(4 \mathrm{mM})$ and/or metabolic inhibitors/modulators (oligomycin $2 \mu \mathrm{M}, 2$,4-dinitrophenol- DNP $200 \mu \mathrm{M}$ and antimycin A + rotetone 1-1 $\mu \mathrm{M}$ ) were injected into each well to reach the desired final working concentration.

\subsection{Oxygen Consumption of PC12 Cells}

Oxygen consumption was performed polarographically using an Oxygraph-2k (Oroboros Instruments, Innsbruck, Austria). Two T75 flasks of approx. 80\% confluent PC12 cells were suspended in $2 \mathrm{~mL}$ incubation medium, containing, in mM: mannitol 225, sucrose 125, Hepes 5, EGTA 0.1, $\mathrm{KH}_{2} \mathrm{PO}_{4}$ $10, \mathrm{MgCl}_{2} 1$, glutamate 5 , malate 5 , succinate $5,0.5 \mathrm{mg} / \mathrm{mL}$ bovine serum albumin (fatty acid-free), $\mathrm{pH}=7.25(\mathrm{KOH})$. Experiments were performed at $37^{\circ} \mathrm{C}$ in $8-12$ parallel wells. Oxygen concentration and oxygen flux ( $\mathrm{pmol} \cdot \mathrm{s}^{-1} \cdot \mathrm{mg}^{-1}$; negative time derivative of oxygen concentration, divided by mitochondrial mass per volume) were recorded using DatLab software (Oroboros Instruments).

\subsection{SDH Activity Measurement}

SDH activity was assessed as described previously [77]. Briefly, the oxidation of succinate by decylubiquinone was coupled to the reduction of dichlorophenolindophenol (DCPIP), and the rate was followed spectrophotometrically at $600 \mathrm{~nm}$ at $30^{\circ} \mathrm{C}$.

\subsection{Statistical Analysis}

All data are expressed as mean \pm SD except where it is indicated otherwise. Statistical analysis was performed using GraphPad Prism 6 software (GraphPad Software Inc., La Jolla California, CA, USA). Gaussian distribution of data was evaluated with Shapiro-Wilks test. In the case of normally distributed data the differences were analyzed by Student's $t$-test, otherwise by rank sum test. Correlation in case of normally distributed data was calculated with a Pearson test, otherwise a Spearmen test was used. $p$ values of $<0.05$ were considered to be statistically significant.

\section{Conclusions}

In summary, we demonstrated for the first time that SDH inhibition either with itaconate, atpenin, or $S D H B$ knockdown had a positive effect on cell viability of chromaffin cells but not on other cell lines which may be related to the glutamine/glutamate metabolism. The aim of our study was to establish a cost-efficient model for the research of novel prognostic factors and therapeutic agents before conducting further, more complex and more expensive studies, however we acknowledge the limitations of our research. Lack of availability of SDHB-mutant animal model developing Pheos [20] warrants other in vitro and in vivo models for deciphering the mechanism contributing to the malignant behavior of these rare tumors. SDHB expression in some SDHB-mutant Pheo/PGL tissues suggests that tumor heterogeneity occurs even in $S D H B$-associated tumors. In addition, by measuring the succinate to fumarate ration in various Pheo tumors it was shown that the remaining SDH activity was highly variable [63]. All together these data suggest that some SDH activity is still maintained in these tumors, therefore knockdown of $S D H B$ by siRNA provides a feasible model for the disease. As itaconate treatment of PC12 cells successfully mimicked the phenotype observed in the $S d h b$ silenced cells, it can be a useful, easily accessible in vitro model for these tumors. The importance of glutamine/glutamate metabolism of cells lacking SDH was confirmed by our in vitro experiments demonstrating the upregulation of GLS-1 after SDH inhibition (either by chemical agents 
or $S d h b$ knockdown) and by the decreased proliferation upon GLS-1 inhibition. The importance of GLS-1 was also reassured by evaluation of expression of GLS-1 in malignant PGL tissues compared to benign tumors. Our data suggests that GLS-1 inhibition in SDH deficient chromaffin cells tumors may represent novel, tumor specific alternatives of therapy in malignant Pheo/PGL where the current treatment options are limited. Moreover, as reliable markers of malignant Pheos are lacking, GLS-1 staining seems to be worthy of further investigations as a potential marker of Pheo/PGL malignancy.

Supplementary Materials: The following are available online at http://www.mdpi.com/2072-6694/12/3/599/s1, Figure S1: SDHB knockdown by Sdhb targeting siRNAs, Figure S2: Succinate to fumarate ratios in cell lines after itaconate or vehicle treatment, Figure S3: Normalized succinate levels after atpenin vs. vehicle treatment: veh: vehicle; suc: succinate, Figure S4: HeatMap, Table S1: Intracellular normalized concentrations of all measured metabolites $(\mu \mathrm{mol} / \mu \mathrm{g})$, Table S2: Intracellular normalized concentrations of all measured metabolites $(\mu \mathrm{mol} / \mu \mathrm{g})$.

Author Contributions: Study design: B.S., A.S., C.C., A.P.; performed LC-MS/MS measurements: K.M., Z.H.; performed Seahorse measurements: J.D.; succinate dehydrogenase activity measurements: C.C.; performed immunostaining of Pheo/PGL staining: I.K.; evaluated results: B.S., K.M., I.K., S.Z., G.B., Z.H., A.S., P.J., K.N., M.T., L.C., H.B., P.I., M.L., C.C., A.P.; 3D cell culturing: L.K., H.B.; performed clinical evaluation of patients: B.S., I.K., J.P., L.C., M.L., A.P.; Statistical analysis and HeatMap construction: B.S., K.M., J.D., O.D.; writing the manuscript: B.S., K.M., I.K., A.P.; supervision and project administration: A.P.; All authors have read and agreed to the published version of the manuscript.

Funding: This research received no external funding.

Acknowledgments: The authors would like to thank Kinga Nemeth for her helpful advice and aid on various technical issues in our study. The authors acknowledge the financial support of Hungarian Academy of Sciences "Lendulet 2013" Grant (A.P.), National Research and Innovation Office (grant NKFIH K125231 to A.P., NKFI-FK128404 to A.S. and NKFIH KH129567 to C.C.), National Bionics Program (A.P., A.S.) and the Higher Education Institutional Excellence Programme of the Ministry of Human Capacities in Hungary, within the framework of the Molecular Biology thematic programme of Semmelweis University (B.S., A.P.).

Conflicts of Interest: The authors declare that they have no competing interests.

\section{References}

1. Hanahan, D.; Weinberg, R.A. Hallmarks of Cancer: The Next Generation. Cell 2011, 144, 646-674. [CrossRef]

2. Beard, C.M.; Sheps, S.G.; Kurland, L.T.; Carney, J.A.; Lie, J.T. Occurrence of pheochromocytoma in Rochester, Minnesota, 1950 through 1979. Mayo Clin. Proc. 1983, 58, 802-804. [PubMed]

3. Baysal, B.E.; Ferrell, R.E.; Willett-Brozick, J.E.; Lawrence, E.C.; Myssiorek, D.; Bosch, A.; van der Mey, A.; Taschner, P.E.; Rubinstein, W.S.; Myers, E.N.; et al. Mutations in SDHD, a mitochondrial complex II gene, in hereditary paraganglioma. Science (New York, NY) 2000, 287, 848-851. [CrossRef] [PubMed]

4. Niemann, S.; Muller, U. Mutations in SDHC cause autosomal dominant paraganglioma, type 3. Nat. Genet. 2000, 26, 268-270. [CrossRef] [PubMed]

5. Astuti, D.; Latif, F.; Dallol, A.; Dahia, P.L.; Douglas, F.; George, E.; Skoldberg, F.; Husebye, E.S.; Eng, C.; Maher, E.R. Gene mutations in the succinate dehydrogenase subunit SDHB cause susceptibility to familial pheochromocytoma and to familial paraganglioma. Am. J. Hum. Genet. 2001, 69, 49-54. [CrossRef]

6. Burnichon, N.; Briere, J.J.; Libe, R.; Vescovo, L.; Riviere, J.; Tissier, F.; Jouanno, E.; Jeunemaitre, X.; Benit, P.; Tzagoloff, A.; et al. SDHA is a tumor suppressor gene causing paraganglioma. Hum. Mol. Genet. 2010, 19, 3011-3020. [CrossRef]

7. Castro-Vega, L.J.; Buffet, A.; De Cubas, A.A.; Cascon, A.; Menara, M.; Khalifa, E.; Amar, L.; Azriel, S.; Bourdeau, I.; Chabre, O.; et al. Germline mutations in FH confer predisposition to malignant pheochromocytomas and paragangliomas. Hum. Mol. Genet. 2014, 23, 2440-2446. [CrossRef]

8. Cascon, A.; Comino-Mendez, I.; Curras-Freixes, M.; de Cubas, A.A.; Contreras, L.; Richter, S.; Peitzsch, M.; Mancikova, V.; Inglada-Perez, L.; Perez-Barrios, A.; et al. Whole-exome sequencing identifies MDH2 as a new familial paraganglioma gene. J. Natl. Cancer Inst. 2015, 107. [CrossRef]

9. Remacha, L.; Comino-Mendez, I.; Richter, S.; Contreras, L.; Curras-Freixes, M.; Pita, G.; Leton, R.; Galarreta, A.; Torres-Perez, R.; Honrado, E.; et al. Targeted Exome Sequencing of Krebs Cycle Genes Reveals Candidate Cancer-Predisposing Mutations in Pheochromocytomas and Paragangliomas. Clin. Cancer Res. 2017, 23, 6315-6324. [CrossRef] 
10. Sciacovelli, M.; Frezza, C. Oncometabolites: Unconventional triggers of oncogenic signalling cascades. Free Radic. Biol. Med. 2016, 100, 175-181. [CrossRef]

11. Briere, J.J.; Favier, J.; Benit, P.; El Ghouzzi, V.; Lorenzato, A.; Rabier, D.; Di Renzo, M.F.; Gimenez-Roqueplo, A.P.; Rustin, P. Mitochondrial succinate is instrumental for HIF1alpha nuclear translocation in SDHA-mutant fibroblasts under normoxic conditions. Hum. Mol. Genet. 2005, 14, 3263-3269. [CrossRef]

12. Selak, M.A.; Armour, S.M.; MacKenzie, E.D.; Boulahbel, H.; Watson, D.G.; Mansfield, K.D.; Pan, Y.; Simon, M.C.; Thompson, C.B.; Gottlieb, E. Succinate links TCA cycle dysfunction to oncogenesis by inhibiting HIF-alpha prolyl hydroxylase. Cancer Cell 2005, 7, 77-85. [CrossRef]

13. Rodriguez-Cuevas, H.; Lau, I.; Rodriguez, H.P. High-altitude paragangliomas diagnostic and therapeutic considerations. Cancer Am. Cancer Soc. 1986, 57, 672-676. [CrossRef]

14. Rodriguez-Cuevas, S.; Lopez-Garza, J.; Labastida-Almendaro, S. Carotid body tumors in inhabitants of altitudes higher than 2000 meters above sea level. Head Neck 1998, 20, 374-378. [CrossRef]

15. Astrom, K.; Cohen, J.E.; Willett-Brozick, J.E.; Aston, C.E.; Baysal, B.E. Altitude is a phenotypic modifier in hereditary paraganglioma type 1: Evidence for an oxygen-sensing defect. Hum. Genet. 2003, 113, $228-237$. [CrossRef]

16. Cerecer-Gil, N.Y.; Figuera, L.E.; Llamas, F.J.; Lara, M.; Escamilla, J.G.; Ramos, R.; Estrada, G.; Hussain, A.K.; Gaal, J.; Korpershoek, E.; et al. Mutation of SDHB is a cause of hypoxia-related high-altitude paraganglioma. Clin. Cancer Res. 2010, 16, 4148-4154. [CrossRef] [PubMed]

17. Brouwers, F.M.; Eisenhofer, G.; Tao, J.J.; Kant, J.A.; Adams, K.T.; Linehan, W.M.; Pacak, K. High frequency of SDHB germline mutations in patients with malignant catecholamine-producing paragangliomas: Implications for genetic testing. J. Clin. Endocrinol. Metab. 2006, 91, 4505-4509. [CrossRef] [PubMed]

18. Amar, L.; Baudin, E.; Burnichon, N.; Peyrard, S.V.; Silvera, S.P.; Bertherat, J.R.M.; Bertagna, X.; Schlumberger, M.; Jeunemaitre, X.; Gimenez-Roqueplo, A.-P.; et al. Succinate Dehydrogenase B Gene Mutations Predict Survival in Patients with Malignant Pheochromocytomas or Paragangliomas. J. Clin. Endocrinol. Metab. 2007, 92, 3822-3828. [CrossRef] [PubMed]

19. Van Hulsteijn, L.T.; Dekkers, O.M.; Hes, F.J.; Smit, J.W.; Corssmit, E.P. Risk of malignant paraganglioma in SDHB-mutation and SDHD-mutation carriers: A systematic review and meta-analysis. J. Med. Genet. 2012, 49, 768-776. [CrossRef] [PubMed]

20. Lepoutre-Lussey, C.; Thibault, C.; Buffet, A.; Morin, A.; Badoual, C.; Benit, P.; Rustin, P.; Ottolenghi, C.; Janin, M.; Castro-Vega, L.J.; et al. From Nf1 to Sdhb knockout: Successes and failures in the quest for animal models of pheochromocytoma. Mol. Cell. Endocrinol. 2016, 421, 40-48. [CrossRef]

21. Chen, L.; Cui, H. Targeting Glutamine Induces Apoptosis: A Cancer Therapy Approach. Int. J. Mol. Sci. 2015, 16, 22830-22855. [CrossRef] [PubMed]

22. DeBerardinis, R.J.; Mancuso, A.; Daikhin, E.; Nissim, I.; Yudkoff, M.; Wehrli, S.; Thompson, C.B. Beyond aerobic glycolysis: Transformed cells can engage in glutamine metabolism that exceeds the requirement for protein and nucleotide synthesis. Proc. Natl. Acad. Sci. USA 2007, 104, 19345-19350. [CrossRef] [PubMed]

23. Zhdanov, A.V.; Waters, A.H.; Golubeva, A.V.; Dmitriev, R.I.; Papkovsky, D.B. Availability of the key metabolic substrates dictates the respiratory response of cancer cells to the mitochondrial uncoupling. Biochim. Biophys. Acta 2014, 1837, 51-62. [CrossRef]

24. Lussey-Lepoutre, C.; Hollinshead, K.E.R.; Ludwig, C.; Menara, M.; Morin, A.; Castro-Vega, L.-J.; Parker, S.J.; Janin, M.; Martinelli, C.; Ottolenghi, C.; et al. Loss of succinate dehydrogenase activity results in dependency on pyruvate carboxylation for cellular anabolism. Nat. Commun. 2015, 6, 8784. [CrossRef]

25. Cardaci, S.; Ciriolo, M.R. TCA Cycle Defects and Cancer: When Metabolism Tunes Redox State. Int. J. Cell Biol. 2012, 2012, 161837. [CrossRef]

26. Mates, J.M.; Segura, J.A.; Martin-Rufian, M.; Campos-Sandoval, J.A.; Alonso, F.J.; Marquez, J. Glutaminase isoenzymes as key regulators in metabolic and oxidative stress against cancer. Curr. Mol. Med. 2013, 13, 514-534. [CrossRef]

27. Whillier, S.; Garcia, B.; Chapman, B.E.; Kuchel, P.W.; Raftos, J.E. Glutamine and alpha-ketoglutarate as glutamate sources for glutathione synthesis in human erythrocytes. FEBS J 2011, 278, 3152-3163. [CrossRef]

28. Chinopoulos, C.; Seyfried, T.N. Mitochondrial Substrate-Level Phosphorylation as Energy Source for Glioblastoma: Review and Hypothesis. ASN Neuro 2018, 10, 1759091418818261. [CrossRef] 
29. Lampa, M.; Arlt, H.; He, T.; Ospina, B.; Reeves, J.; Zhang, B.; Murtie, J.; Deng, G.; Barberis, C.; Hoffmann, D.; et al. Glutaminase is essential for the growth of triple-negative breast cancer cells with a deregulated glutamine metabolism pathway and its suppression synergizes with mTOR inhibition. PLoS ONE 2017, 12, e0185092. [CrossRef]

30. Wang, J.B.; Erickson, J.W.; Fuji, R.; Ramachandran, S.; Gao, P.; Dinavahi, R.; Wilson, K.F.; Ambrosio, A.L.; Dias, S.M.; Dang, C.V.; et al. Targeting mitochondrial glutaminase activity inhibits oncogenic transformation. Cancer Cell 2010, 18, 207-219. [CrossRef]

31. Van den Heuvel, A.P.; Jing, J.; Wooster, R.F.; Bachman, K.E. Analysis of glutamine dependency in non-small cell lung cancer: GLS1 splice variant GAC is essential for cancer cell growth. Cancer Biol. Ther. 2012, 13, 1185-1194. [CrossRef] [PubMed]

32. Cassago, A.; Ferreira, A.P.; Ferreira, I.M.; Fornezari, C.; Gomes, E.R.; Greene, K.S.; Pereira, H.M.; Garratt, R.C.; Dias, S.M.; Ambrosio, A.L. Mitochondrial localization and structure-based phosphate activation mechanism of Glutaminase C with implications for cancer metabolism. Proc. Natl. Acad. Sci. USA 2012, 109, 1092-1097. [CrossRef] [PubMed]

33. Imperiale, A.; Moussallieh, F.-M.; Sebag, F.; Brunaud, L.; Barlier, A.; Elbayed, K.; Bachellier, P.; Goichot, B.; Pacak, K.; Namer, I.-J.; et al. A New Specific Succinate-Glutamate Metabolomic Hallmark in Sdhx-Related Paragangliomas. PLoS ONE 2013, 8, e80539. [CrossRef] [PubMed]

34. Kitazawa, S.; Ebara, S.; Ando, A.; Baba, Y.; Satomi, Y.; Soga, T.; Hara, T. Succinate dehydrogenase B-deficient cancer cells are highly sensitive to bromodomain and extra-terminal inhibitors. Oncotarget 2017, 8, 28922-28938. [CrossRef]

35. Lee, C.-H.; Gundem, G.; Lee, W.; Chen, Y.-B.; Cross, J.R.; Dong, Y.; Redzematovic, A.; Mano, R.; Wei, E.Y.; Cheng, E.H.; et al. Persistent Severe Hyperlactatemia and Metabolic Derangement in Lethal SDHB-Mutated Metastatic Kidney Cancer: Clinical Challenges and Examples of Extreme Warburg Effect. JCO Precis. Oncol. 2017. [CrossRef]

36. Michelucci, A.; Cordes, T.; Ghelfi, J.; Pailot, A.; Reiling, N.; Goldmann, O.; Binz, T.; Wegner, A.; Tallam, A.; Rausell, A.; et al. Immune-responsive gene 1 protein links metabolism to immunity by catalyzing itaconic acid production. Proc. Natl. Acad. Sci. USA 2013, 110, 7820. [CrossRef]

37. Patel, T.R.; McFadden, B.A. Caenorhabditis elegans and Ascaris suum: Inhibition of isocitrate lyase by itaconate. Exp. Parasitol. 1978, 44, 262-268. [CrossRef]

38. McFadden, B.A.; Purohit, S. Itaconate, An Isocitrate Lyase-Directed Inhibitor in Pseudomonas Indigofera. J. Bacteriol. 1977, 131, 136-144. [CrossRef]

39. Daniels, B.P.; Kofman, S.B.; Smith, J.R.; Norris, G.T.; Snyder, A.G.; Kolb, J.P.; Gao, X.; Locasale, J.W.; Martinez, J.; Gale, M., Jr.; et al. The Nucleotide Sensor ZBP1 and Kinase RIPK3 Induce the Enzyme IRG1 to Promote an Antiviral Metabolic State in Neurons. Immunity 2019, 50, 64-76. [CrossRef]

40. Nemeth, B.; Doczi, J.; Csete, D.; Kacso, G.; Ravasz, D.; Adams, D.; Kiss, G.; Nagy, A.M.; Horvath, G.; Tretter, L.; et al. Abolition of mitochondrial substrate-level phosphorylation by itaconic acid produced by LPS-induced Irg1 expression in cells of murine macrophage lineage. FASEB J. 2016, 30, 286-300. [CrossRef]

41. Cordes, T.; Wallace, M.; Michelucci, A.; Divakaruni, A.S.; Sapcariu, S.C.; Sousa, C.; Koseki, H.; Cabrales, P.; Murphy, A.N.; Hiller, K.; et al. Immunoresponsive Gene 1 and Itaconate Inhibit Succinate Dehydrogenase to Modulate Intracellular Succinate Levels. J. Biol. Chem. 2016, 291, 14274-14284. [CrossRef] [PubMed]

42. Weiss, J.M.; Davies, L.C.; Karwan, M.; Ileva, L.; Ozaki, M.K.; Cheng, R.Y.S.; Ridnour, L.A.; Annunziata, C.M.; Wink, D.A.; McVicar, D.W. Itaconic acid mediates crosstalk between macrophage metabolism and peritoneal tumors. J. Clin. Investig. 2018, 128, 3794-3805. [CrossRef] [PubMed]

43. Davies, L.C.; Rice, C.M.; Palmieri, E.M.; Taylor, P.R.; Kuhns, D.B.; McVicar, D.W. Peritoneal tissue-resident macrophages are metabolically poised to engage microbes using tissue-niche fuels. Nat. Commun. 2017, 8, 2074. [CrossRef] [PubMed]

44. Horsefield, R.; Yankovskaya, V.; Sexton, G.; Whittingham, W.; Shiomi, K.; Omura, S.; Byrne, B.; Cecchini, G.; Iwata, S. Structural and computational analysis of the quinone-binding site of complex II (succinate-ubiquinone oxidoreductase): A mechanism of electron transfer and proton conduction during ubiquinone reduction. J. Biol. Chem. 2006, 281, 7309-7316. [CrossRef] [PubMed]

45. Miyadera, H.; Shiomi, K.; Ui, H.; Yamaguchi, Y.; Masuma, R.; Tomoda, H.; Miyoshi, H.; Osanai, A.; Kita, K.; Omura, S. Atpenins, potent and specific inhibitors of mitochondrial complex II (succinate-ubiquinone oxidoreductase). Proc. Natl. Acad. Sci. USA 2003, 100, 473-477. [CrossRef] 
46. Sharma, S.; Wang, J.; Cortes Gomez, E.; Taggart, R.T.; Baysal, B.E. Mitochondrial complex II regulates a distinct oxygen sensing mechanism in monocytes. Hum. Mol. Genet. 2017, 26, 1328-1339. [CrossRef]

47. Wang, H.; Huwaimel, B.; Verma, K.; Miller, J.; Germain, T.M.; Kinarivala, N.; Pappas, D.; Brookes, P.S.; Trippier, P.C. Synthesis and Antineoplastic Evaluation of Mitochondrial Complex II (Succinate Dehydrogenase) Inhibitors Derived from Atpenin A5. ChemMedChem 2017, 12, 1033-1044. [CrossRef]

48. Gimenez-Roqueplo, A.P.; Dahia, P.L.; Robledo, M. An update on the genetics of paraganglioma, pheochromocytoma, and associated hereditary syndromes. Horm. Metab. Res. Horm. Stoffwechs. Horm. Metab. 2012, 44, 328-333. [CrossRef]

49. Dahia, P.L.M. Pheochromocytoma and paraganglioma pathogenesis: Learning from genetic heterogeneity. Nat. Rev. Cancer 2014, 14, 108-119. [CrossRef]

50. Gimenez-Roqueplo, A.P.; Favier, J.; Rustin, P.; Rieubland, C.; Crespin, M.; Nau, V.; Khau Van Kien, P.; Corvol, P.; Plouin, P.F.; Jeunemaitre, X. Mutations in the SDHB gene are associated with extra-adrenal and/or malignant phaeochromocytomas. Cancer Res. 2003, 63, 5615-5621.

51. Neumann, H.P.; Pawlu, C.; Peczkowska, M.; Bausch, B.; McWhinney, S.R.; Muresan, M.; Buchta, M.; Franke, G.; Klisch, J.; Bley, T.A.; et al. Distinct clinical features of paraganglioma syndromes associated with SDHB and SDHD gene mutations. JAMA 2004, 292, 943-951. [CrossRef] [PubMed]

52. Ricketts, C.J.; Forman, J.R.; Rattenberry, E.; Bradshaw, N.; Lalloo, F.; Izatt, L.; Cole, T.R.; Armstrong, R.; Kumar, V.K.; Morrison, P.J.; et al. Tumor risks and genotype-phenotype-proteotype analysis in 358 patients with germline mutations in SDHB and SDHD. Hum. Mutat. 2010, 31, 41-51. [CrossRef] [PubMed]

53. Andrews, K.A.; Ascher, D.B.; Pires, D.E.V.; Barnes, D.R.; Vialard, L.; Casey, R.T.; Bradshaw, N.; Adlard, J.; Aylwin, S.; Brennan, P.; et al. Tumour risks and genotype-phenotype correlations associated with germline variants in succinate dehydrogenase subunit genes SDHB, SDHC and SDHD. J. Med Genet. 2018, 55, 384-394. [CrossRef]

54. Gimenez-Roqueplo, A.P.; Favier, J.; Rustin, P.; Rieubland, C.; Kerlan, V.; Plouin, P.F.; Rotig, A.; Jeunemaitre, X. Functional consequences of a SDHB gene mutation in an apparently sporadic pheochromocytoma. J. Clin. Endocrinol. Metab. 2002, 87, 4771-4774. [CrossRef]

55. Pollard, P.J.; Briere, J.J.; Alam, N.A.; Barwell, J.; Barclay, E.; Wortham, N.C.; Hunt, T.; Mitchell, M.; Olpin, S.; Moat, S.J.; et al. Accumulation of Krebs cycle intermediates and over-expression of HIF1alpha in tumours which result from germline FH and SDH mutations. Hum. Mol. Genet. 2005, 14, 2231-2239. [CrossRef]

56. Pollard, P.J.; El-Bahrawy, M.; Poulsom, R.; Elia, G.; Killick, P.; Kelly, G.; Hunt, T.; Jeffery, R.; Seedhar, P.; Barwell, J.; et al. Expression of HIF-1alpha, HIF-2alpha (EPAS1), and their target genes in paraganglioma and pheochromocytoma with VHL and SDH mutations. J. Clin. Endocrinol. Metab. 2006, 91, 4593-4598. [CrossRef]

57. Liu, Y.; Pang, Y.; Caisova, V.; Ding, J.; Yu, D.; Zhou, Y.; Huynh, T.T.; Ghayee, H.; Pacak, K.; Yang, C. Targeting NRF2-Governed Glutathione Synthesis for SDHB-Mutated Pheochromocytoma and Paraganglioma. Cancers 2020, 12, 280. [CrossRef]

58. Pang, Y.; Lu, Y.; Caisova, V.; Liu, Y.; Bullova, P.; Huynh, T.T.; Zhou, Y.; Yu, D.; Frysak, Z.; Hartmann, I.; et al. Targeting NAD(+)/PARP DNA Repair Pathway as a Novel Therapeutic Approach to SDHB-Mutated Cluster I Pheochromocytoma and Paraganglioma. Clin. Cancer Res. 2018, 24, 3423-3432. [CrossRef]

59. Sulkowski, P.L.; Sundaram, R.K.; Oeck, S.; Corso, C.D.; Liu, Y.; Noorbakhsh, S.; Niger, M.; Boeke, M.; Ueno, D.; Kalathil, A.N.; et al. Krebs-cycle-deficient hereditary cancer syndromes are defined by defects in homologous-recombination DNA repair. Nat. Genet. 2018, 50, 1086-1092. [CrossRef]

60. Stenman, A.; Zedenius, J.; Juhlin, C.C. Over-diagnosis of potential malignant behavior in MEN 2A-associated pheochromocytomas using the PASS and GAPP algorithms. Langenbecks Arch. Surg. 2018, 403, 785-790. [CrossRef]

61. Saxena, N.; Maio, N.; Crooks, D.R.; Ricketts, C.J.; Yang, Y.; Wei, M.H.; Fan, T.W.; Lane, A.N.; Sourbier, C.; Singh, A.; et al. SDHB-Deficient Cancers: The Role of Mutations That Impair Iron Sulfur Cluster Delivery. J. Natl. Cancer Inst. 2016, 108. [CrossRef] [PubMed]

62. Lorendeau, D.; Rinaldi, G.; Boon, R.; Spincemaille, P.; Metzger, K.; Jager, C.; Christen, S.; Dong, X.; Kuenen, S.; Voordeckers, K.; et al. Dual loss of succinate dehydrogenase (SDH) and complex I activity is necessary to recapitulate the metabolic phenotype of SDH mutant tumors. Metab. Eng. 2017, 43, 187-197. [CrossRef] 
63. Lendvai, N.; Pawlosky, R.; Bullova, P.; Eisenhofer, G.; Patocs, A.; Veech, R.L.; Pacak, K. Succinate-to-fumarate ratio as a new metabolic marker to detect the presence of SDHB/D-related paraganglioma: Initial experimental and ex vivo findings. Endocrinology 2014, 155, 27-32. [CrossRef] [PubMed]

64. Lampropoulou, V.; Sergushichev, A.; Bambouskova, M.; Nair, S.; Vincent, E.E.; Loginicheva, E.; Cervantes-Barragan, L.; Ma, X.; Huang, S.C.-C.; Griss, T.; et al. Itaconate Links Inhibition of Succinate Dehydrogenase with Macrophage Metabolic Remodeling and Regulation of Inflammation. Cell Metab. 2016, 24, 158-166. [CrossRef] [PubMed]

65. Rupprecht, A.; Moldzio, R.; Modl, B.; Pohl, E.E. Glutamine regulates mitochondrial uncoupling protein 2 to promote glutaminolysis in neuroblastoma cells. Biochim. Biophys. Acta Bioenerg. 2019, 1860, 391-401. [CrossRef]

66. Yelamanchi, S.D.; Jayaram, S.; Thomas, J.K.; Gundimeda, S.; Khan, A.A.; Singhal, A.; Keshava Prasad, T.S.; Pandey, A.; Somani, B.L.; Gowda, H. A pathway map of glutamate metabolism. J. Cell Commun. Signal. 2016, 10, 69-75. [CrossRef]

67. Metallo, C.M.; Gameiro, P.A.; Bell, E.L.; Mattaini, K.R.; Yang, J.; Hiller, K.; Jewell, C.M.; Johnson, Z.R.; Irvine, D.J.; Guarente, L.; et al. Reductive glutamine metabolism by IDH1 mediates lipogenesis under hypoxia. Nature 2011, 481, 380-384. [CrossRef]

68. Wise, D.R.; Ward, P.S.; Shay, J.E.; Cross, J.R.; Gruber, J.J.; Sachdeva, U.M.; Platt, J.M.; DeMatteo, R.G.; Simon, M.C.; Thompson, C.B. Hypoxia promotes isocitrate dehydrogenase-dependent carboxylation of alpha-ketoglutarate to citrate to support cell growth and viability. Proc. Natl. Acad. Sci. USA 2011, 108, 19611-19616. [CrossRef]

69. Mullen, A.R.; Wheaton, W.W.; Jin, E.S.; Chen, P.H.; Sullivan, L.B.; Cheng, T.; Yang, Y.; Linehan, W.M.; Chandel, N.S.; DeBerardinis, R.J. Reductive carboxylation supports growth in tumour cells with defective mitochondria. Nature 2011, 481, 385-388. [CrossRef]

70. Elgogary, A.; Xu, Q.; Poore, B.; Alt, J.; Zimmermann, S.C.; Zhao, L.; Fu, J.; Chen, B.; Xia, S.; Liu, Y.; et al. Combination therapy with BPTES nanoparticles and metformin targets the metabolic heterogeneity of pancreatic cancer. Proc. Natl. Acad. Sci. USA 2016, 113, E5328-E5336. [CrossRef]

71. Saskoi, E.; Hujber, Z.; Liko, I.; Meszaros, K.; Sarkadi, B.; Matyasi, B.; Kovacs, A.; Patthy, L.; Nyiro, G.; Sváb, G.; et al. The Arg244His missense mutation in SDHB-1 leads to altered metabolism in Caenorhabditis elegans: A new disease model. Endocr. Abstr. 2019. [CrossRef]

72. Szoboszlai, N.; Guo, X.; Ozohanics, O.; Olah, J.; Gomory, A.; Mihucz, V.G.; Jeney, A.; Vekey, K. Determination of energy metabolites in cancer cells by porous graphitic carbon liquid chromatography electrospray ionization mass spectrometry for the assessment of energy metabolism. Anal. Chim. Acta 2014, 819, 108-115. [CrossRef] [PubMed]

73. Krencz, I.; Sebestyen, A.; Papay, J.; Jeney, A.; Hujber, Z.; Burger, C.D.; Keller, C.A.; Khoor, A. In situ analysis of mTORC1/2 and cellular metabolism-related proteins in human Lymphangioleiomyomatosis. Hum. Pathol. 2018, 79, 199-207. [CrossRef]

74. Konosu-Fukaya, S.; Omata, K.; Tezuka, Y.; Ono, Y.; Aoyama, Y.; Satoh, F.; Fujishima, F.; Sasano, H.; Nakamura, Y. Catecholamine-Synthesizing Enzymes in Pheochromocytoma and Extraadrenal Paraganglioma. Endocr. Pathol. 2018, 29, 302-309. [CrossRef] [PubMed]

75. Jády, A.G.; Nagy, Á.M.; Kőhidi, T.; Ferenczi, S.; Tretter, L.; Madarász, E. Differentiation-Dependent Energy Production and Metabolite Utilization: A Comparative Study on Neural Stem Cells, Neurons, and Astrocytes. Stem Cells Dev. 2016, 25, 995-1005. [CrossRef] [PubMed]

76. Nagy, A.M.; Fekete, R.; Horvath, G.; Koncsos, G.; Kriston, C.; Sebestyen, A.; Giricz, Z.; Kornyei, Z.; Madarasz, E.; Tretter, L. Versatility of microglial bioenergetic machinery under starving conditions. Biochim. Biophys. Acta (BBA) Bioenerg. 2018, 1859, 201-214. [CrossRef]

77. Tan, A.K.; Ramsay, R.R.; Singer, T.P.; Miyoshi, H. Comparison of the structures of the quinone-binding sites in beef heart mitochondria. J. Biol. Chem. 1993, 268, 19328-19333.

(C) 2020 by the authors. Licensee MDPI, Basel, Switzerland. This article is an open access article distributed under the terms and conditions of the Creative Commons Attribution (CC BY) license (http://creativecommons.org/licenses/by/4.0/). 